NBER WORKING PAPER SERIES

\title{
WHAT EXPLAINS THE GERMAN LABOR MARKET MIRACLE IN THE GREAT RECESSION?
}

\author{
Michael C. Burda \\ Jennifer Hunt \\ Working Paper 17187 \\ http://www.nber.org/papers/w17187 \\ NATIONAL BUREAU OF ECONOMIC RESEARCH \\ 1050 Massachusetts Avenue \\ Cambridge, MA 02138 \\ June 2011
}

We are grateful to Markus Poschke for many insightful discussions, and to participants in the spring Brookings Papers on Economic Activity conference, discussants Mike Elsby and John Haltiwanger and editors David Romer and Justin Wolfers, as well as Wendy Carlin, Bernd Fitzenberger, Dan Hamermesh and Johannes Schmieder for valuable comments and suggestions. Gerhard Bosch, Wolfram Brehmer, John Galbraith, Hermann Gartner, Thomas Haipeter, Bart Hobijn, Sabine Klinger, Jürgen Pechmann, Claus Schnabel, Sigrid Stallhofer, Viktor Steiner, Hans-Jürgen Urban, Susanne Wanger, Frank- Jürgen Weise and Ottheinrich von Weitershausen provided data and useful background information. Femke Schmarbeck and Jean-Philippe Garant were excellent research assistants throughout the project. Maren Brede, Christina Resnicek, and Marko Ringmann constructed an invaluable repository of Handelsblatt articles on business optimism over the period 2005-2009. Burda acknowledges support from the CRC 649 of the German Science Foundation. Hunt is also affiliated with the CEPR and IZA, and acknowledges financial support from the Social Science and Humanities Research Council of Canada. The views expressed herein are those of the authors and do not necessarily reflect the views of the National Bureau of Economic Research.

NBER working papers are circulated for discussion and comment purposes. They have not been peerreviewed or been subject to the review by the NBER Board of Directors that accompanies official NBER publications.

(C) 2011 by Michael C. Burda and Jennifer Hunt. All rights reserved. Short sections of text, not to exceed two paragraphs, may be quoted without explicit permission provided that full credit, including $\odot$ notice, is given to the source. 
What Explains the German Labor Market Miracle in the Great Recession?

Michael C. Burda and Jennifer Hunt

NBER Working Paper No. 17187

June 2011

JEL No. E24,E32,J6

\begin{abstract}
$\underline{\text { ABSTRACT }}$
Germany experienced an even deeper fall in GDP in the Great Recession than the United States, with little employment loss. Employers' reticence to hire in the preceding expansion, associated in part with a lack of confidence it would last, contributed to an employment shortfall equivalent to 40 percent of the missing employment decline in the recession. Another 20 percent may be explained by wage moderation. A third important element was the widespread adoption of working time accounts, which permit employers to avoid overtime pay if hours per worker average to standard hours over a window of time. We find that this provided disincentives for employers to lay off workers in the downturn. Although the overall cuts in hours per worker were consistent with the severity of the Great Recession, reduction of working time account balances substituted for traditional government-sponsored short-time work.
\end{abstract}

Michael C. Burda

Faculty of Business and Economics

Humboldt University Berlin

Spandauer Str. 1

D-10178 Berlin

Germany

burda@wiwi.hu-berlin.de

Jennifer Hunt

Department of Economics

McGill University

Leacock Building Room 443

855 Sherbrooke Street West

Montreal, QC, H3A 2T7

CANADA

and NBER

jennifer.hunt@alum.mit.edu 
Like the United States, Germany recently experienced a recession of a magnitude not seen since the Great Depression. German GDP fell 6.6 percent from its peak in 2008Q1, exceeding the 4.1 percent peak-to-trough decline in the United States from 2007Q4 (figure 1, top left). Yet the labor market experiences of the two countries could hardly have been more different. As the top right panel of figure 1 shows, the U.S. unemployment rate soared from 4.5 percent in the first quarter of 2007 to a high of 10.0 percent by the end of 2009, while the German unemployment rate actually declined over the period, only briefly rising from 7.4 percent to 7.9 percent in late 2008 and early 2009. The contrast is mirrored in the path of employment (figure 1, bottom left): while U.S. employment fell 5.6 percent, German employment fell a mere 0.5 percent before resuming an upward path. Germany's 3.4 percent reduction in person-hours worked was larger than its decline in employment, yet still much smaller than the 7.6 percent fall in the United States (figure 1, bottom right). These key changes and the peak and trough quarters in each country are summarized in table 1 .

The German and U.S. labor market experiences during this period are almost polar opposites in the international context. Among pre-1990 members of the Organisation for Economic Co-operation and Development (OECD), only Spain and Ireland had larger percentage reductions in employment in 2008-09 than the United States, and only Australia, which experienced no recession, fared better than Germany in terms of employment (U.S. Bureau of Labor Statistics 2010). Figure 1 also plots outcomes for the United Kingdom, a more representative country: its GDP decline was similar to that of the United States, but its recovery has been slower, and its increase in unemployment and reduction in employment lie in between the trajectories of the United States and Germany.

The German experience in 2008-09 contrasts not merely with that of the United States, but also with previous German recessions, as figure 2 illustrates. In terms of the output decline (top panel), the 2008-09 recession was unusually severe. By comparison, GDP declined by only 2.4 percent from peak to trough in the 1973-75 recession, little more than a third of the 2008-09 decline; the peak-to-trough declines in the other three recessions depicted were even smaller. The virtual absence of any employment decline in 2008-09 is also unprecedented among recent recessions, as the middle panel shows. In the 1973-75 recession, employment fell 4.3 percent from its peak to its trough 11 quarters later. The 2008-09 decline in person-hours seems less remarkable (bottom panel): person-hours fell rapidly, retracing the early path of the 1973-75 decline. 
Considering the much greater decline in GDP in the Great Recession, however, the similarity of the declines in person-hours is a surprise.

In this paper we investigate the reasons for this significant deviation from historical experience in the German labor market response to the 2008-09 recession. We highlight the fact that employment rose less than expected in the preceding expansion, given changes in GDP and labor costs, and that half of this shortfall can be explained using data on employers' business expectations. Employers lacked confidence that the boom would last, or were perhaps uncertain about how long it would last, and therefore they hired less than would have been predicted given contemporaneous conditions. Consequently, they were able to avoid costly layoffs when the recession arrived. Our survey of reporting by the Handelsblatt business newspaper confirms a general impression that firms downsized and restructured in the 2005-06 period, out of caution about the extent and persistence of the business upturn. The missing employment increase in the boom accounts for 41 percent of the missing employment decline in the recession, and 23 percent of that missing decline can be linked to pessimistic expectations in the expansion.

If labor costs responded more flexibly than in the past to mitigate employment losses, this could also contribute to explaining the unusually mild labor market response to the recession. However, the fall in labor costs came too late to stem employment losses. Some previous analysts (Boysen-Hogrefe and Groll 2010, Gartner and Klinger 2010) have instead suggested a role for the stagnation of wages beginning in 2001, coinciding with a decline in the power of labor unions. We find that wage moderation may explain 20 percent of the missing employment decline in the recession.

Although we cannot account for about 40 percent of the missing decline in employment, we believe that a personnel management tool known as working time accounts, which became increasingly common in labor union contracts over time, played a role in moderating the labor market downturn. Working time accounts permit employers to use overtime for free as long as working time is cut by an equal amount within a defined window of time. When the recession arrived, workers had built up large surpluses in these accounts, which would have had to be compensated at the overtime premium if the workers were then laid off. Alternatively, employers could have kept these workers employed at low hours until the accounts were drawn down to zero, and then laid them off, but by then the time until the expected upswing might not have been long 
enough to amortize the normal layoff and hiring costs that would have been incurred. Employers therefore laid off fewer workers in the 2008-09 recession than in earlier recessions when working time accounts were less widespread, preferring to draw down the surpluses by cutting workers' hours (at unchanged pay).

Many analysts have assumed that these cuts came in addition to the cuts that would have occurred in the absence of the accounts, and that the additional flexibility in hours per worker thus played a key role in moderating employment losses. ${ }^{1}$ However, use of the accounts largely substituted for other methods of reducing hours per worker, including the traditional government short-time work scheme. Overall, although the decline in hours per worker was very large, it was consistent with expectations based on historical experience and the depth of the recession. The unexpected development in the recession was the number of workers able to retain their job and experience this decline in hours per worker.

We believe that the 2003-05 labor market reforms helped reduce unemployment, possibly with a lag that meant the reforms acted as a brake on rising unemployment in the recession (as proposed by Gartner and Klinger 2010), and that they may therefore also have acted as a brake on employment losses. We present a simple model of dynamic labor demand with an intensive and an extensive margin that suggests why working time accounts and other recent reforms in German labor market institutions constitute a regime change that is consistent with the labor market miracle. This model treats employment (the extensive margin) as a quasi-fixed factor, while the marginal cost of hours rises at the intensive margin. The model explains why regime change and expectations interact to affect the dynamic behavior of employment and hours per worker. Reforms and other changes in the labor market caused the quasi-fixity of employment to increase, and employers to react more slowly to changes in economic conditions, effectively attaching more weight to future expected changes in forcing variables such as wages or demand conditions.

We cannot evaluate whether employers correctly expected a shorter recession than usual, and hence hoarded more labor than usual, as available expectations data refer only to 6 months ahead. Reporting in Handelsblatt did suggest that, especially by 2009, firms were concerned about losing skilled workers, who are becoming increasingly specialized and difficult to replace over

\footnotetext{
${ }^{1}$ These analysts include Schneider and Graef (2010), Klös and Schäfer (2010), Möller (2010), and Sachverständigenrat (2010); a less decisive role is attributed by Schaz and Spitznagel (2010). Boysen-Hogrefe and Groll (2010) are more skeptical.
} 
time. It is plausible that employers are increasingly reluctant to part with a greater share of their workers because of the increasing cost of refilling specialized vacancies.

Despite the role of weak hiring in the 2005-07 expansion in explaining the resilience of the labor market in the recession, the moniker "labor market miracle" may still be appropriate, given the amount of the puzzle left unquantified and possibly due to private and public labor market reforms. We deemphasize flexibility in cutting hours per worker only because it played an equally important role in moderating the employment decline in previous, "nonmiraculous" recessions. Such flexibility could be beneficial for the United States, but it would be premature to endorse this approach without considering all the institutions governing U.S. labor relations (see Abraham and Houseman 1993, Boeri and Brueckner 2011).

\section{Background to the 2008-09 Recession in Germany}

The nature of the Great Recession in Germany was quite different from that of its U.S. counterpart. Whereas the United States suffered a decline in domestic demand driven by falling net wealth of the household sector, Germany had experienced no housing bubble, and instead the German output decline was driven by the collapse of world trade. Figure 3, which plots the major components of GDP since 1970, contrasts the stability of German consumption in the 2000s with the large swings in imports and, particularly, exports in that decade. The government did have to bail out several banks, brought down by their international and, especially, U.S. investments, and there was concern that German banks remained undercapitalized in 2010 (OECD 2010b). German exporters saw world trade as overreacting to events in the United States, and they may have expected a recovery of favorable demand conditions in export-oriented sectors and regions of Germany that had been booming previously. In the event, the BRIC countries (Brazil, Russia, India, and China) and many key export markets in Eastern Europe did recover rapidly.

The 2008-09 recession should be put in the context of the recent history of the German economy and labor market. The economy performed sluggishly, in terms of both growth and unemployment, from the end of the unification boom in 1993 until the expansion that began in 2005. Unification with the former East Germany may have played a role: the resulting increase in government debt could have led consumers to revise their estimates of future wealth downward, depressing consumption, and higher payroll taxes may have increased unemployment (Carlin and 
Soskice 2009). The central bank reduced the money supply to deal with postunification inflation, leaving annual inflation below 2 percent from 1995 through 2010; Germany is thought to have entered the European monetary union in 1999 at an exchange rate that overvalued the deutsche mark (Sinn 1999).

An important labor market development was the stagnation of wages from 2001 until 2008, after decades of growth. This wage moderation is related to the decline in the power of labor unions in Germany since the mid-1990s (Dustmann and others 2009). Between 1996 and 2008, union coverage shrank from 70 percent to 55 percent in the western part of the country and from 57 percent to 40 percent in the east (Ellguth and Kohaut 2009); wage drift (payment of wages above the collectively bargained rate) also declined in the 2000s (Lesch 2010). Pressure on wages in the 2000s, and hence on union bargaining power, may have come initially from the need for a real devaluation after European monetary union; it was sustained by the increased attractiveness of offshoring as the European Union expanded eastward in 2004 (Sinn 2005). Another contributing factor may have been the 2003-05 labor market reforms, which we discuss in detail below.

The upturn of 2005-07 marked a return to growth and a significant reduction in unemployment. German firms restructured their arrangements with labor to improve efficiency, especially through increasing the flexibility of working hours and decentralizing the determination of pay. Whereas unions had conceded greater flexibility in the 1980s and 1990s in return for a shorter work week (Hunt 1999), in the 2000s they did so in return for employment security (reduced outsourcing of production abroad) and more training (Carlin and Soskice 2009). Many of these initiatives originated in eastern Germany, where firms struggled in the 1990s to achieve competitiveness. German firms are generally considered to have been in good financial condition on the eve of the Great Recession.

\section{Decomposing the Miracle}

We begin the analysis by quantifying the contributions of productivity and person-hours to the downturn in output in 2008-09, and by further splitting person-hours into its components: hours per worker, unemployment, and labor force participation. 


\section{II.A. Hours per Worker and Productivity}

Two facts implicit in figure 2 will be useful for our decomposition, and we make them explicit in figure 4. First, the left panel of figure 4 shows that hours per worker fell rapidly in the Great Recession. However, their path is roughly comparable to that in the shallower 1973-75 recession. Second, the right panel shows that hourly labor productivity declined substantially. From a historical perspective, this is the true anomaly: the 4 percent reduction in productivity in the 2008-09 recession contrasts with strong increases in productivity in the four previous recessions.

\section{II.B. Lessons from a Simple Decomposition}

To quantify the contributions of the various components, we start with the following decomposition of the change in output:

$$
\begin{aligned}
\Delta Y / Y & =\Delta(Y / H) /(Y / H)+\Delta H / H \\
& =\Delta(Y / H) /(Y / H)+\Delta(H / L) /(H / L)+\Delta(L / L F) /(L / L F)+\Delta L F / L F,
\end{aligned}
$$

where $Y$ is real GDP, $H$ is person-hours, $L$ is the number of persons employed, and $L F$ is the labor force. This relationship comes from log differentiation of an expression of output as the product of output per hour and person-hours, with the latter in turn written as the product of hours per worker, 1 minus the unemployment rate, and the change in the labor force.

Using equation 1, table 2 decomposes (in logarithms) the drop in output from peak to trough in both Germany and the United States, as well as for the longer period 2008Q1-2009Q4 in both countries, which is more relevant for employment adjustment. ${ }^{2}$ The results are quantitatively similar when a Hodrick-Prescott (HP) trend $(\lambda=1600)$ calculated over 1970Q1-2010Q3 is removed (not shown). The table shows two striking differences between the two countries. First, the behavior of hourly productivity over the recession is qualitatively different, rising in the United States but falling in Germany, and the implied adjustment in person-hours is much smaller in Germany. Second, the decline in person-hours in the United States is associated with an increase in

\footnotetext{
${ }^{2}$ German employment rises in this table, unlike in table 1, because the focus on the peak-to-trough period for GDP misses the employment decline.
} 
unemployment, whereas in Germany it is principally due to a reduction in hours per worker. In neither country did a change in the labor force contribute significantly to the output decline.

The Great Recession in Germany represents a significant departure from Okun's law, the statistical relationship between real GDP growth and the change in the unemployment rate, as can be seen in table 1 . Since $\Delta(L / L F) /(L / L F)$ is approximately equal to the change in the unemployment rate, Okun's relationship becomes a "law" when elements of the right-hand side of equation 1 exhibit a stable correlation structure. A priori, hours per worker and labor force participation should fluctuate procyclically, but the evidence on the cyclicality of hourly productivity is less clear-cut. ${ }^{3}$ Evidently, an already unstable Okun's relationship became untethered in Germany during the Great Recession. ${ }^{4}$ We now turn to the factors responsible for its shift.

\section{II.C. Hours per Worker versus Number of Workers, Given Person-Hours}

Although Germany and the United States experienced comparable recessions and little change in the labor force, German firms in the aggregate reduced person-hours worked by less than U.S. firms did. But given person-hours, did German firms exploit the intensive versus the extensive margin of hours reduction differently from U.S. firms, or differently from their own behavior in past recessions? That the United States and Germany adjust hours differently over the cycle has been well established since Katharine Abraham and Susan Houseman (1993) showed that, relative to the United States, cyclical adjustment in the German labor market occurs more in terms of hours per worker rather than in terms of number of workers ("bodies"; see also Schaz and Spitznagel 2010). ${ }^{5}$ In the United States, one-third of the adjustment to a reduction in person-hours typically comes about through reductions in hours per worker, and two-thirds through reductions in the number of workers. Michael Elsby, Bart Hobijn, and Ayşegül Şahin (2010) confirm that the Great Recession was little different, with a 30-70 split.

\footnotetext{
${ }^{3}$ The real business cycle research agenda is predicated on a procyclical correlation of labor productivity with output, albeit a weak one (see, for example, Cooley 1995). In annual data for the period 1947-2009, we compute a correlation of growth in real GDP per hour and real GDP growth of 0.49; for the period 1990-2009 the correlation declines to 0.03, and it falls further, to -0.05 in the last decade. See Galí and van Rens (2010) and www.econ.upenn.edu/ manovski, accessed March 6, 2011.

${ }^{4}$ Regressions of changes in unemployment on changes in log output and a constant for the period 1970Q1-2010Q3 show that the Okun relationship accounts for only 7 percent of the variance in Germany, as opposed to almost 50 percent in the United States, with an Okun coefficient in Germany that is one-fifth the corresponding U.S. estimate.

${ }^{5}$ Their data were for manufacturing only.
} 
The extensive-versus-intensive margin decomposition for recent German recessions is displayed in table 3 for both the raw data and their HP-detrended counterparts. With the exception of the 1991-93 episode, at least half of the raw hours reduction can be accounted for by reductions in hours per worker (last column). Although all the person-hours adjustment in the 2008-09 recession occurred through hours per worker, this was not unprecedented and is comparable to what happened in the 1979-82 downturn. With an adjustment share for hours per worker of only 9 percent, the 1991-93 recession is an outlier, associated, we believe, with the expiry of reunification-related policies that kept hours per worker low in the former East Germany (Will 2010). The reduction in hours per worker was smaller in 2008-09 than in the 1973-75 and 1979-82 recessions.

The raw results thus confirm that Germany adjusts more along the intensive margin than does the United States. Because of a downward trend in hours per worker that ended in the 2000s, HP detrending reduces the share of adjustment due to hours per worker and increases this share in 2008-09 relative to other recessions. The 2008-09 recession was unusual in that employers could not benefit from an ongoing reduction in hours per worker in order to adjust.

\section{The German Puzzle: More Detail}

We have shown that German labor market performance in the Great Recession derives from a relatively standard reduction in hours per worker and a remarkably small reduction in employment. But to what extent is this outcome itself unusual, given the sharp drop in GDP and a moderation of labor costs? Does the recent period represent a deviation from standard operating procedure in German labor markets, and if so, for which sectors? In this section we explore this question in more detail.

\section{III.A. Hours per Worker}

The German labor market outcome that has attracted the most attention from both German and U.S. analysts is the reduction in working hours per worker. We have shown that the 2008-09 decline in hours per worker was similar to the 1973-75 fall despite a much larger reduction in GDP. The question that naturally arises is, how different was the decline in hours per worker, conditioning on output and labor costs? We formalize this question using out-of-sample forecasts 
based on reduced-form regressions of hours per worker $(H / L)$ on GDP $(Y)$ and labor costs per worker $(w)$, the latter including all social security contributions. ${ }^{6}$ Since our focus is on the business cycle, we favor a regression in one-quarter differences to capture cyclical fluctuations in $H / L:^{7}$

$$
\Delta \log (H / L)_{t}=\delta_{0}+\delta_{1} \Delta \log Y_{t}+\delta_{2} \Delta \log w_{t}+\Delta \mu_{t}
$$

We also extend this to estimate an error correction model:

$$
\Delta \log (H / L)_{t}=\delta_{3}+\delta_{4} \Delta \log Y_{t}+\delta_{5} \Delta \log w_{t}+\delta_{6} \log (H / L)_{t-1}+\delta_{7} \log Y_{t-1}+\delta_{8} \log w_{t-1}+\Delta \omega_{t}
$$

It is important to include information on the major recessions of the 1970s and 1980s as well as the mild recession of the early 2000 s and the atypical postunification slump, and therefore we chain the West German and the unified German time series using overlapping 1991 data (specifically the first quarter). We begin estimation with the first year available, 1970, and continue through 2003. We stop at 2003 because of the introduction that year of the Hartz labor market reforms, which we describe in detail below. Standard errors are Newey-West based on four lags.

The results of these regressions are reported in in the first two columns of table 4, and the predicted values of $H / L$, formed from cumulating predicted changes in $H / L$, are plotted in figure 5 . It is evident that actual hours per worker were in secular decline from 1970 to 2003 before flattening out in 2004, then falling sharply in the 2008-09 recession, and snapping back in the recovery. As already revealed by the HP detrending in table 3, a large component of the declines observed in the 1970s recessions reflected the secular trend in hours per worker. Both regression models predict a fall in hours per worker similar to the actual fall, as is seen most clearly when the predicted changes are cumulated from 2008Q1, when GDP peaked. What is different in 2008-09 is

\footnotetext{
${ }^{6}$ We use aggregate, quarterly, seasonally adjusted data from the German Federal Statistical Office. The labor cost statistics provided in the national income accounts do not reflect the savings to employers from using short-time work, because both the benefits to the workers and the full social security payments are initially paid by the employer and only subsequently rebated. However, throughout our analysis we use labor cost numbers adjusted to reflect these rebates. We use data from the Statistische Jahrbüch on the accounts of the Bundesagentur für Arbeit and its predecessor, transforming these yearly data into quarterly data according to the distribution over the year of hours lost to short-time work. This adjustment is trivial in magnitude at the aggregate level except in the 1973-75 and 2008-09 recessions, and even in these recessions it is very small.

${ }^{7}$ A regression in levels, which picks up low-frequency fluctuations, yields a statistically insignificant coefficient on GDP.
} 
not the magnitude of the reduction in hours per worker, but that it occurred in the absence of an existing trend. We interpret this finding as evidence that methods of adjustment have changed, a topic to which we return below.

\section{III.B Employment}

To analyze employment, we begin by estimating the error correction model in equation 3 for both the level of employment. Again, our aim is to analyze fluctuations over the cycle. Because employment fluctuates less than hours per worker at high frequency, the coefficient on GDP is considerably higher in levels regressions, which capture low-frequency variation. Our preferred specification is therefore that in levels, with a trend included and with the covariates lagged to avoid endogeneity. We include four lags of GDP for consistency with later regressions, although only the first has a statistically significant coefficient here (higher-order lags of labor costs generally have insignificant coefficients):

$$
\log L_{t}=\delta_{9}+\delta_{10} \log Y_{t-1}+\delta_{11} \log Y_{t-2}+\delta_{12} \log Y_{t-3}+\delta_{13} \log Y_{t-4}+\delta_{14} \log w_{t-1}+\delta_{15} t+\mu_{t}
$$

The regression results are reported in the last two columns of table 4, and the actual and predicted values are plotted in figure 6. As already seen in figures 1 and 2, actual employment rises in the boom of 2005-07, but instead of plunging in 2008-09, as in previous recessions, it merely levels off. The figure shows that, according to our preferred specification, employment would have been expected to fall by a large amount, similar to that in the 1973-74 recession, given the movements in GDP and labor costs per worker. The error correction model fits the data poorly and suggests that the modest downturn was not very surprising. We do not find this specification convincing.

Interestingly, according to both specifications, employment should have risen more than it did in the upturn that immediately preceded the 2008-09 recession, even though the upturn was unconditionally large. ${ }^{8}$ This suggests the possibility that fewer workers than expected were laid off

\footnotetext{
${ }^{8}$ Logeay and Zwiener (2008) also make this observation by comparing this expansion with the previous one.
} 
in the recession because they had not been hired in the boom, a possibility that figures prominently in our analysis later on. ${ }^{9}$

\section{III.C. Composition Effects: Where Are the Missing Job Losses?}

In order to understand the behavior of labor markets in the Great Recession, it is important to know which industries behaved unusually. Discussion of the U.S. recession has focused on the financial, construction, durable consumption goods, and retail services industries, which had swelled in the previous two decades. In the case of Germany, we look for patterns in the sectoral structure of employment declines. Can we find sectors in which person-hours and employment should have contracted, given the drop in demand and past behavior, but where in fact they did not?

The upper panel of figure 7 traces value added by sector (omitting agriculture) from 1970 to 2010 (as before, the data are chained to remove the jump at unification). The 2008 slump in value added in manufacturing is striking in the historical context: the fall of 23 percent between 2007Q4 and 2009Q1 is considerably larger even than the loss in value added that accompanied the postunification recession and the collapse of eastern German manufacturing in the early 1990s. By contrast, employment in this sector fell by a modest amount in 2008-09 by historical standards, as the lower panel shows. The figure also shows that the manufacturing boom beginning in 2005 was large by historical standards (upper panel) but was not accompanied by a historically large employment increase (lower panel).

Construction is also a cyclical sector, in terms of both value added and employment. The unification-related boom and bust in both series are clear, and the partial recovery in 2006 may also be seen. The trade sector, which includes wholesale and retail trade as well as the hospitality industry and transportation, shows signs of a small boom, bust, and recovery in both series from 2006 to 2010. The FIRE (finance, insurance, real estate, and other business services) and other services (health, education, and other public or personal services) sectors are not cyclical and display upward trends throughout the period. There has been a significant increase in employment in temporary agencies in Germany since their deregulation in 2003 (Burda and Kvasnicka 2006).

\footnotetext{
${ }^{9}$ We have verified that no similar pattern of prediction errors occurs when the 1970 s and 1980 s boom-and-bust cycles are predicted out of sample.
} 
Despite their name, temporary help workers work under the same contractual conditions as other employees, including employment protection. Regardless of where they are actually working, their employment and value added are attributed to the FIRE category in the national income accounts. Manufacturing generally accounts for a large share of the use of temporary workers (Burda and Kvasnicka 2006), but the distribution of its use over time is unknown.

To predict where job losses would have been expected based on past experience, we employ the sector-specific analogue of equation 4 :

(5) $\log L_{i t}=\gamma_{0 i}+\beta_{1 i} \log V_{i t-1}+\beta_{2 i} \log V_{i t-2}+\beta_{3 i} \log V_{i t-3}+\beta_{4 i} \log V_{i t-4}+\gamma_{1 i} \log w_{t-1}+\gamma_{2 i} t+\eta_{i t}$,

where $V$ is value added and the is index sectors. Value added, in turn, is a function of the components of GDP (GDP alone is a poor predictor of value added) and a linear trend:

$$
\log V_{i t}=\alpha_{0 i}+\alpha_{1 i} \log C_{t}+\alpha_{2 i} \log I_{t}+\alpha_{3 i} \log G_{t}+\alpha_{4 i} \log X_{t}+\alpha_{5 i} \log Z_{t}+\alpha_{6 i} t+\varepsilon_{i t},
$$

where $C$ is consumption, $I$ investment, $G$ government spending, $X$ exports, and $Z$ imports. Using these equations, we can judge how much of an unpredictable employment change is due to a surprise in how employment reacted to a change in value added (the change in the residual from equation $5, \Delta \eta_{i t}$ ) and how much is due to unexpected developments in value added itself ( $\beta_{1 i}$ times the change in the lagged residual from equation $6, \Delta \varepsilon_{i t-1}$, plus the terms corresponding to the other three lags, $\left.\Sigma_{j} \beta_{j i} \Delta \varepsilon_{i t-j}\right)$. We focus on the three more cyclical sectors, since prediction errors in employment for FIRE and other services stem principally from the slowing of upward trends, which means we are examining employment of core, nontemporary workers. We also estimate equation 5 for the whole economy (including temporary workers). As before, we estimate the equations using data from 1970 to 2003 . Table 5 presents key numbers for the 2008-09 recession and the preceding expansion, and the underlying regression results are reported in table 6 .

The first row in the top panel of table 5 shows that whereas aggregate employment was almost unchanged in the recession, it would have been expected to fall by $4.2 \log$ points given value added (GDP) and labor costs, implying a 3.9-log-point prediction error (the numbers in the first two columns do not sum to the third because of rounding). The second row shows that employment in manufacturing fell only $3.8 \mathrm{log}$ points in the bust, compared with an expected fall of $17.6 \log$ points given value added and labor costs, for a prediction error of $13.7 \log$ points. This 
13.7-log-point gap may be considered the missing employment decline in manufacturing. To tie manufacturing to the missing aggregate employment decline (given GDP), it is necessary to consider the unexpected change in value added in manufacturing. In the next two columns of table 5 , we present information on the first lag, which is generally the most influential: value added plunged $23.6 \log$ points, considerably more than would have been predicted given the components of GDP (16.4 log points) when all four lags of value added are considered, offsetting by $5.7 \log$ points the error that would have been made in predicting the change in employment based on the components of GDP and labor costs. Summing the components of the third and sixth columns, based on the components of GDP and labor costs, we find that manufacturing employment would have been expected to fall by $8.0 \log$ points more than it did.

There was a slight increase in employment in construction during the recession (by $0.9 \log$ point), close to the predicted increase of $0.4 \log$ point based on value added and labor costs. For construction, all lags of value added play a significant role, and so the fourth and fifth columns are less informative than for other sectors; the last column shows that when all lags are taken into account, there was no surprise in the evolution of value added given the components of GDP. The statistical stability of construction employment is not a surprise, for two reasons: first, Germany experienced no real estate boom in the run-up to the recession, and second, a large component of the stimulus program was directed to government construction projects.

Our findings for the trade sector show excess hires of $2.1 \mathrm{log}$ points, with no offsetting effect from value added, which is well predicted. The missing cyclical job losses (of core workers) appear, therefore, to be from manufacturing.

We observed in figure 6 that the 2005-07 expansion created fewer jobs than expected, and in figure 7 that the expansion in manufacturing did not appear to generate many jobs in the sector. We examine this more formally in the bottom panel of table 5. Aggregate employment rose $3.9 \log$ points but would have been predicted to rise by $5.5 \mathrm{log}$ points based on value added (GDP) and labor costs, for a shortfall of $1.6 \mathrm{log}$ points. Did the expected decline in employment during the bust not materialize because the workers had not been hired in the boom? If so, the magnitude of the hiring shortfall is $1.6 / 3.9=41$ percent of the layoff shortfall in the recession. The last three rows of the table indicate that the missing employment increase (in core workers) was concentrated in manufacturing. 


\section{Economic and Institutional Explanations}

We have established that GDP in the Great Recession fell more in Germany than in the United States, while person-hours fell less. Yet in that downturn as well as in the preceding boom, German employment responded less than usual to changes in GDP and labor costs, and so the putative miracle lies in the muted response of employment, in particular in manufacturing (at least for core, nontemporary workers). We now turn to some possible economic and institutional explanations for these statistical findings.

\section{IV.A. A Simple Model of Dynamic Labor Demand}

Employment would respond less to changes in GDP and labor costs if costs of adjusting employees have risen, or if employers doubt the persistence of those changes. To help organize our thinking about possible causes of changing firm behavior, we use a standard model of dynamic labor demand to study the impact of changing costs of labor input as well as that of expectations. ${ }^{10}$ For simplicity, we study a representative firm that acts competitively in both product and labor markets and has no capital investment decision to make, allowing us to focus on the extensive and intensive margins of hours adjustment. In period $t=0$, the representative firm chooses plans for employment $\left\{L_{t}\right\}$ and hours per worker $\left\{\theta_{t}\right\}$ so as to maximize real expected discounted profits:

$$
E_{0} \sum_{t=0}^{\infty} \beta^{t}\left[P_{t} Y_{t}-W_{t} \Omega\left(\theta_{t}\right) L_{t} \theta_{t}-\Phi L_{t}-\frac{c}{2}\left(L_{t}-L_{t-1}\right)^{2}\right],
$$

subject to the production function $Y_{t}=\mathrm{f}\left(H_{\mathrm{t}}\right)$, where $H_{t}=\theta_{t} L_{t}$ plus an initial condition $L_{0}$, taking as given the sequences of hourly base wages $\left\{W_{t}\right\}$ and prices $\left\{P_{t}\right\}$, both measured in terms of a numeraire good. ( $\mathrm{E}_{0}$ denotes the expectation conditional on period $t$ information). Costs of changing the level of core employment $L_{t}$ from the past period's value $L_{t-1}$ are quadratic in the change and parametrized by $c$. An hour of a worker's time who is already working $\theta_{t}$ hours costs

\footnotetext{
${ }^{10}$ See Treadway (1970) and Sargent (1978). Other models of labor demand involving lumpy costs of adjustment may also be employed (Hamermesh 1989, Hamermesh and Pfann 1996), but in aggregation their implications are difficult to distinguish from conventional models with convex costs of adjustment (Khan and Thomas 2003).
} 
$W_{t} \Omega\left(\theta_{t}\right)$, with $\Omega^{\prime}>0$ and constant elasticity $\eta_{\Omega \theta \cdot}{ }^{11}$ There is a fixed per worker employment charge $\Phi$.

Optimal behavior of the firm is straightforward to derive and is presented in the appendix. It is important to distinguish between long-run steady-state and short-run dynamic behavior. In the long run, two equations govern the intensive and extensive margins (dropping subscripts):

$$
\begin{aligned}
& W \Omega(\theta) \eta_{\Omega \theta}=\frac{\Phi}{\theta} \\
& \frac{P f^{\prime}(\theta L)}{W \Omega(\theta)}=1+\eta_{\Omega \theta} .
\end{aligned}
$$

Given $W, P, \Phi$, and the function $\Omega$, steady-state hours per worker $(\theta)$ are determined by equation 7 . Given $\theta$, equation 8 determines employment $L$ and total hours $H=\theta L$. It is straightforward to show that the base wage $W$ reduces, while the fixed cost $\Phi$ increases, steady-state hours per worker. An increase in $\eta_{\Omega \theta}$, holding all else constant, will reduce hours per worker but have an ambiguous effect on $L$.

Although these long-run implications are well understood, the model also contains predictions for high-frequency changes in optimal allocation of hours across the intensive and the extensive margins, given current and expected future wages $W_{t}$ and output prices $P_{t}$ (the latter being a proxy for aggregate demand). Using carets to denote percentage deviations from the steady state, we can describe optimal employment and hours per worker by the following two recursive equations:

$$
\begin{aligned}
& \hat{L}_{t}=\lambda \hat{L}_{t-1}+\frac{\lambda \Phi}{c \beta L} \sum_{t=0}^{\infty}(\lambda \beta)^{\tau}\left[\varphi_{P} \hat{P}_{t+\tau}-\varphi_{W}\left(\hat{W}_{t+\tau}-\hat{P}_{t+\tau}\right)\right] \\
& \hat{\theta}_{t}=-\eta_{\theta t} \hat{L}_{t}-\eta_{\theta W}\left(\hat{W}_{t}-\hat{P}_{t}\right)
\end{aligned}
$$

\footnotetext{
${ }^{11}$ A more realistic formal model would relate overtime in working time accounts (sustained cumulated deviations of $\theta$ from its normal value) to employment adjustment costs directly by carrying the latter as a state variable, so that the more extensive the use made of such accounts in a boom, the more costly the adjustment downward in the aftermath. Such a model is formally more difficult to handle, and so we have taken the short cut of treating employment adjustment costs as parametric and studying the differential behavior of employment across different parameter values.
} 
where the elasticities $\varphi_{P}, \varphi_{W}, \eta_{\theta L}$, and $\eta_{\theta W}$ are all positive and $\lambda$ is the stable root $(0<\lambda<1)$ of the difference equation governing optimal employment. Details can be found in the appendix.

The above equations characterize optimal labor demand as a short-term reaction via hours per worker and a longer-term reaction via employment, which depends on its own past value with persistence determined by $\lambda$. This crucial parameter not only summarizes the sluggishness of employment but also represents the weight applied to expected values of future output price and wages as determinants of employment. Expectations of future demand and factor prices play a central role in shaping the reaction of employment to current shocks. Analogous to the permanent income theory of consumption, the model predicts that for given model parameters, employment reacts more strongly to changes in current aggregate demand and wages when these are expected to be permanent rather than temporary. From equation 9 , the larger is $\lambda$, the greater the weight applied to future versus present determinants of labor demand. Crucially for what follows, an increase in the persistence parameter $\lambda$ could be attributed to an increase in the adjustment cost parameter $c$ or to a decrease in $\eta_{\Omega \theta}$, the steepness with which the cost of using the intensive margin rises, or to both. In the following sections, we search for specific institutional and economic changes in German labor markets that relate to these theoretical implications.

\section{IV.B. Flexibility in Reducing Hours per Worker}

Although our analysis suggests that the decline in hours per worker in the 2008-09 recession was not surprising given the depth of the recession, it makes sense to start where so much attention has been directed in both the United States and Germany. In this section we explain why, despite the availability of new tools to adjust hours per worker, there was no surprise.

SHORT-TIME WORK (KURZARBEIT) One central reason often adduced for U.S.-German labor market differences is the differing systems of compensation in the two countries: the German system combines high firing costs, lengthy severance notice periods, and selective access to shorttime compensation subsidies from the government, all of which encourage employers to cut hours per worker rather than bodies. In contrast, firing in the United States is a low-cost means of employment reduction; short-time pay is rarely used and designed only to insure very low earners against hours reductions. Yet it is noteworthy that the use of short-time work did not prevent large 
rises in unemployment in previous German recessions. The highly regarded German short-time work system (Kurzarbeit) is frequently cited in the business press as a central factor mitigating sharp rises in unemployment in Germany. ${ }^{12}$

Short-time work has existed in Germany for a century. The underlying idea is that a firm in "unavoidable" financial difficulties due to a documented shortfall of orders can apply in writing to the employment office, which administers the unemployment insurance program and active labor market policies, for short-time support. The firm then refrains from layoffs but reduces workers' hours and variable pay in proportion. Workers receive between 60 and 67 percent of the net pay they would have received for the hours not demanded. Firms pay workers this Kurzarbeitergeld ("short-time money") and are later reimbursed by the employment agency through the unemployment insurance fund. In previous recessions, firms were expected to pay social security and other contributions of workers in full, causing average labor costs to rise with the reduction of hours. Implementation of short-time work at the firm level must be agreed to and is monitored by the works council (the establishment-level organization charged with representing workers' interests), which may help protect workers from potential abuse of the system by management.

The short-time work scheme was expanded aggressively in several ways in the course of the Great Recession. Firms could claim subsidies for up to 24 months instead of 6 , and the required minimum number of affected workers was reduced. In late 2008 and early 2009, the Federal Employment Agency (Bundesagentur für Arbeit) took out newspaper advertisements encouraging firms to apply for short-time subsidies. In addition, the government assumed half the social insurance costs of the affected workers under a number of specific conditions. Even temporary help workers in Germany, who work on regular contracts for their agencies, were eligible for short-time subsidies from March 2009 onward and remain eligible until March 2012. Figure 8 shows that despite the intensity of these efforts, the number of person-hours lost to short-time work was comparable to that in the shallower $1973-75$ recession. ${ }^{13}$ On the basis of the volume of reduced time, the use of short-time work represented the equivalent of about 400,000 jobs in 2009

\footnotetext{
${ }^{12}$ Ralph Atkins, "Europe Reaps the Rewards of State-Sponsored Short-Time Jobs," Financial Times, October 28, 2009. OECD (2010a) evaluates short-time programs in different countries.

${ }^{13}$ This has already been noted by Herzog-Stein and Seifert (2010).
} 
(Schneider and Graef 2010), or 1 percent of total employment. Tito Boeri and Herbert Bruecker (2011) point out, however, that such calculations overstate the number of jobs saved. ${ }^{14}$

WORKING TIME ACCOUNTS Some analysts attribute the small magnitude of the fall in employment to reductions in hours per worker of another type. The system of working time accounts (Arbeitszeitkonten) allows employers the freedom to increase hours above standard hours with no immediate payment, as long as hours are reduced at some future time with no cut in takehome pay, leaving hours at the standard when averaged over a window of time. The number of hours the employer owes the worker, which may be negative, is tracked in the worker's working time account. The share of workers with such an account rose from 33 percent in 1998 to 48 percent in 2005, and the average window in 2005 was 30 weeks (Gross and Schwarz 2007). ${ }^{15}$

The model of the previous section predicts that working time accounts would reduce labor costs and increase labor demand, inducing a positive scale effect and substitution from the extensive to the intensive labor margin. ${ }^{16}$ The last effect occurs because the accounts reduce overtime premia and the sensitivity of wage costs to the intensive margin, possibly to zero. Personhours should increase, but the effect on employment is ambiguous. Over the firm's cycle, working time accounts reduce overtime pay and the cost of adjusting hours per worker, so hours per worker should fluctuate more, while employment should adjust more sluggishly. ${ }^{17}$

Table 7 shows exactly what accounted for the decline in hours per worker between 2008 and 2009 (analysis is difficult at quarterly frequency and impossible by sector). Annual hours per worker fell by 41.3 hours, or 3.1 percent. The largest contributing factor was short-time work, which accounted for 13.4 hours, or 32 percent of the total decline. A reduction in standard weekly hours was the next biggest factor (accounting for about one-quarter of the reduction), followed by approximately equal contributions from reductions in overtime, reductions in working time account

\footnotetext{
${ }^{14}$ There is a special short-time work scheme for firms that are restructuring, which involves employees "working" zero hours. Although this scheme was used massively in the east in the early 1990s, in 2009 it accounted for only 8.6 percent of short-time payments (and therefore of short-time hours).

${ }^{15}$ Gross and Schwarz (2007) also document that employers sometimes violate some provisions of the agreements, and it is possible that in practice the windows are longer than 30 weeks. Still, working time accounts would have waned in importance compared with short-time work as 2009 wore on.

${ }^{16}$ In a model with physical capital, substitution from capital to labor would also occur.

${ }^{17}$ The lower reallocation of labor in a recession brought about by working time accounts may lower the economy's productivity, but this is offset by firms' higher productivity during periods of smaller fluctuations.
} 
balances, and the increase in the share of workers who are part-time (17 to 19 percent each). Previous authors (see footnote 1) have pointed to the contribution of working time accounts as evidence that hours per worker fell more than in previous recessions thanks to this newly expanded institution (presumably 17 percent more), thus allowing more jobs to be saved. Mechanically, the drawing down of working time accounts corresponds to 0.5 percent of annual hours and hence could be considered to have "saved" 0.5 percent of employment. The second column of table 7 confirms the number cited above of a "savings" equivalent to 1 percent of jobs through short-time work.

Firms do not immediately save money by reducing surpluses in working time accounts, so it is not immediately obvious why firms would do so in a severe downturn rather than lay off workers. However, a worker's account must be paid off if the worker is laid off, either as a severance payment including the overtime premium, or in the form of low hours at full pay before the layoff takes effect. ${ }^{18}$ All things equal, firms using working time accounts will have an incentive to postpone layoffs at the start of a recession, instead drawing down workers' surplus time in their accounts. Once a worker's account is at zero, the worker may be laid off, but by then the upturn may be sufficiently near that it is no longer worthwhile incurring the normal firing and hiring costs that apply to all workers. In November 2007 a ruling of the Federal Labor Court (Bundesarbeitsgericht 2010) strengthened the layoff disincentive by holding that an employer could not lay off a worker if any co-worker doing the same job had a surplus in his or her account. ${ }^{19}$ The analysis is more complex when the availability of the government short-time scheme is taken into account. It is no longer unambiguous that firms using working time accounts lay off less, but they will lay off less if the accumulated surplus hours are sufficiently large, a condition likely to have been fulfilled in 2008 .

A different consideration is that a firm that has workers with working time account surpluses has less incentive to use the short-time work scheme than a firm that does not, because using short-time work does not draw down the working time accounts. A surplus firm that uses

\footnotetext{
${ }^{18}$ When a worker with a working time account works an hour of overtime, she gets paid nothing, but one hour is credited to her account. The balance reverts to zero if she is given an hour off with pay within the window. If she is laid off with an hour's balance in her account, she must be compensated at the normal hourly wage plus the overtime premium.

${ }^{19}$ For more details on how working accounts worked in the Great Recession, see Zapf and Brehmer (2010). For a detailed description in English of working time accounts, see Seifert (2004).
} 
short-time work during a recession will have to buy out its workers' surplus hours, because the window within which the working time accounts must be in balance will expire. If the surpluses are very large, the firm will prefer to draw them down rather than use short-time work, as the shorttime compensation will not outweigh the excess hours compensation the firm would have to pay the workers. Thus, it is theoretically possible, as well as consistent with the fact that short-time work was not used more than in the milder 1973-75 recession, that the increased use of working time accounts crowded out short-time work in the 2008-09 recession. Reductions in hours per worker through working time accounts may not have come entirely at the expense of short-time work. In previous recessions, the downward trend in hours per worker contributed to the reduction in hours per worker, and working time accounts may also have compensated for the lack of such a trend in the Great Recession. However, the first column of table 4 shows that this trend was -0.36 log point per quarter, which is large compared with the 0.5 percent yearly reduction in hours due to working time accounts (second column of table 7). Hours per worker must have adjusted along other margins in the recession to compensate for the cessation of the trend.

UNCOMPENSATED HOURS REDUCTIONS: WORKING TIME CORRIDORS Another relatively new, but less frequently used, option for firms wishing to reduce hours per worker involves the so-called working time corridors (Arbeitszeitkorridore). These are commonly included in the "opening clauses" conceded by unions in negotiations with employers as their bargaining power has continued to weaken in the past decade. Opening clauses permit firms to take extraordinary measures in extraordinary times, subject to agreement by the works council. A firm invoking an opening clause with a working time corridor provision may reduce total working hours, reducing its labor costs proportionately. This option is inferior to short-time work for the worker, because the lost income is not replaced by a government benefit. It is superior to short-time work for the firm in one important respect: unlike in the case of short-time work, all fixed costs (such as annual vacation and Christmas pay) and social security contributions are reduced proportionately, as well as wages (Hoff 2009). However, the hours reductions permitted are typically on the order of 15 percent, much less than is possible with short-time work. Perhaps for this reason, opening clauses appear to have been used little to reduce working time in the 2008-09 recession. A 2009 survey of works councils indicated that only 8 percent of firms were using this measure, compared with 30 
percent that were drawing down surpluses or building up deficits in working time accounts, 20 percent that were using short-time work, and 13 percent that were adjusting through vacation time (Bogedan and others 2009). The data behind the decomposition of table 7 do not allow cuts through working time corridors to be identified, but they would appear under changes in standard weekly hours.

\section{IV.C. Labor Costs}

The small magnitude of the employment decline in the 2008-09 recession could be explained if labor costs had become more flexible and the adjustment to the drop in labor demand came through a decline in labor costs, rather than a decline in employment as in the past. Such a decline could have occurred through the use of opening clauses in union contracts, which, in addition to permitting the working time corridors mentioned above, sometimes permit employers to cut hourly wages in a downturn. Perhaps surprisingly, this option appears to have been used infrequently: the 2009 survey of works councils indicates that only 11 percent of firms did so (Bogedan and others 2009). A decline in labor costs could also have occurred through the introduction of subsidies to offset payroll taxes for employers using short-time work; such subsidies were introduced for the first time in July 2009. However, the amount paid out in shorttime payments and social security refunds in 2009 was a mere 0.3 percent of the wage bill. ${ }^{20}$

The top left panel of figure 9 plots hourly labor costs for the period 1970-2010Q3 (again chained to eliminate a jump at unification); the top right panel focuses on the period 2004-10. Labor cost growth fell to zero in 2001 but then surged just as the recession began in 2008, as contracts negotiated in the previous year came into force. The aggregate wage share dropped sharply from 1982 to the recession (bottom two panels). Labor costs did fall in 2009, but only from the second quarter onward, after GDP had ceased to decline, and therefore too late to stem job losses, since our regressions suggest that aggregate employment does not respond faster to labor costs than to GDP.

\footnotetext{
${ }^{20}$ Payroll taxation is significant in Germany, at about 35 percent of aggregate gross pay currently, compared with only about 12 to 13 percent in the United States, and it has a tendency to rise in recessions (Burda and Weder 2010), for two reasons. First, there is a fixed upper bound on contributions, as in the United States, and second, federal governments tend to raise payroll taxes during recessions to keep the social insurance funds that they finance operating in the black.
} 
Certain authors, particularly Jens Boysen-Hogrefe and Dominik Groll (2010) and Hermann Gartner and Sabine Klinger (2011), stress instead the importance of the wage moderation that has occurred since 2001 as providing the conditions under which a recession would lead to only moderate employment losses. To get a sense of the magnitudes that might be involved, we examine the counterfactual that labor costs per worker had resumed growth at the rate that had prevailed from 1995 to 2000, $1.12 \log$ points per year, but that GDP followed its actual course. Our own estimate of the compensated elasticity of labor demand is -0.5 (see third column of table 4); a value closer to the consensus in the literature is -0.7 (Peichl and Siegloch 2010). GDP fell for four quarters beginning in 2008Q1, and over this length of time wages in the counterfactual would have risen $1.12 \log$ points, reducing employment by $0.7 \times 1.12=0.8 \log$ point (assuming an elasticity of -0.7). Wage moderation could thus account for $0.8 / 3.9=20$ percent of the missing employment decline. Wage moderation appears to deepen the puzzle of sluggish employment growth in the expansion, but it may have had a muted effect if employers did not expect this moderation to last, as would be implied by a dynamic labor demand model.

\section{IV.D. Labor Market Efficiency}

A set of landmark labor reforms was passed in the twilight of the left-of-center government led by Chancellor Gerhard Schröder. In March 2003 Schröder put forward the "Agenda 2010," which sought to increase flexibility in German labor markets. A commission headed by Peter Hartz, a top Volkswagen executive, and consisting of representatives of unions, management, and government, put forward a number of proposals, many of which were passed by the federal parliament and put into effect in 2003-05. The reforms may loosely be grouped into those reducing reservation wages (and therefore reducing wages), those increasing the efficiency of the job search process (and therefore increasing wages), and those allowing employers more flexibility (probably reducing wages). We focus initially on the first two categories. ${ }^{21}$

The Hartz IV law, which reformed unemployment benefits, is particularly likely to have reduced reservation wages. The amount of recent work experience required for eligibility was increased, the duration of the benefits cut, and the onus of finding a job put for the first time on the unemployed person rather than the local employment agency. Sanctions for refusing job offers

\footnotetext{
${ }^{21}$ An excellent source in German for information on the reforms is "Die Hartz Reformen" (www.hartz-iv-iii-ii-i.de/, accessed March 4, 2011). For a discussion in English, see Ochel (2005).
} 
were increased and applied more frequently. The follow-on unemployment assistance program, which provided means-tested benefits potentially indefinitely, was merged with the less generous social welfare program. The reforms most likely to have improved job search efficiency were Hartz I, which enlisted private firms to help workers search for jobs, and Hartz III, which reorganized the Federal Employment Agency.

Theoretically, these reforms should have reduced unemployment, and there is some evidence that they did. For example, the unemployment rate of 50- to 54-year-olds, the group experiencing the largest reduction in benefit duration, began falling in 2005 relative to the rate for 25- to 49-year-olds and continued to do so throughout the recession (graph available from the authors). Long-term unemployed (defined as workers with unemployment spells of 1 year or more) peaked as a share of the unemployed in 2007 and fell through the recession to 45.5 percent in 2009. ${ }^{22}$ René Fahr and Uwe Sunde (2009) and Klinger and Thomas Rothe (2010) find that the efficiency of the job matching function increased, and Gartner and Klinger (2011) observe that the Beveridge curve shifted inward and continues to do so. Overall, the hypothesis that the Hartz reforms reduced unemployment by increasing employment, possibly with a lag that led their effect to continue into the recession, is plausible. The potential magnitude is difficult to judge, however.

The third set of reforms sought to provide more flexibility to employers. In 2003 the threshold size for firms subject to layoff rules was raised from 5 to 10 workers. Hartz II introduced so-called mini-jobs, or part-time forms of employment involving monthly income of no greater than $€ 400$, which were exempt from most social security taxes. Hartz I significantly deregulated the temporary agency sector, leading to more competition for regular employment from temporary workers. These last two reforms are likely to have contributed to wage moderation.

How much additional flexibility did the Hartz reforms afford employers? The deregulation of the temporary agency sector is considered the most important of the reforms in this respect. It gave individual employers flexibility to vary employment without incurring hiring or firing costs, and the share of temporary workers rose from 1.3 percent of employment in 2005 to 2.8 percent in 2007-08 (Bundesagentur für Arbeit 2011). But the effect on the flexibility of the aggregate economy was smaller, as most temporary agency workers have permanent contracts with their

\footnotetext{
${ }^{22}$ See table 3 in "Employment and Labour Markets: Key Tables from the OECD" http://dx.doi.org/10.1787/207523422010-table3, accessed June 3, 2011.
} 
agency. Employment of temporary workers did fall as soon as the recession hit, well before permanent employment responded (Bundesagentur für Arbeit 2011). Because temporary workers are less attached to the labor force, it is easier for temporary agencies to reduce employment by attrition, and it is becoming more common for them to hire workers initially on temporary contracts (Burda and Kvasnicka 2006). But the magnitude of the adjustment should be put in perspective. The total employment decline among temporary workers, at 205,000 (Bundesagentur für Arbeit 2011), represents only 0.5 percent of total employment at its 2008 peak. The extra flexibility for the aggregate economy appears small, making it plausible that the moderating effect of working time accounts on employment fluctuations was more important.

\section{IV.E. The Role of Expectations in the Boom and the Bust}

Employment could have responded more inertially to the 2008-09 recession because employers expected it to be shorter than usual. This recession, although deep, was in fact of shorter duration than other postwar recessions, with the possible exception of the 1973-75 episode, which had a faster recovery. Employers may have expected a short downturn, based on the expectation that world trade would recover quickly. We also hypothesize that employers expected the 2005-07 boom to be short-lived. We investigate these possibilities using data on firms' expectations and an analysis of the business press, before considering variants of the expectations-based hypotheses.

EMPLOYER EXPECTATIONS DATA We make use of indices of the current business situation and business expectations derived from surveys conducted by the Ifo Institute for Economic Research. Ifo surveys about 7,000 firms each month, asking whether the current situation in the firm is good, satisfactory, or poor, and whether the firm expect the next 6 months to be more favorable, unchanged from, or less favorable than present. Ifo calculates the expectations "balance" as the difference between the percentage shares of positive and negative responses. These indices are available for the whole German economy, and separately for manufacturing, construction, wholesale trade, and retail trade. There is no obvious way to deal with unification, and so we simply join the series (for most series there is no jump at unification).

Figure 10 presents these two monthly series for the above four sectors, along with quarterly value added in the corresponding sector, normalized to equal 100 at the start of the 2005 boom. 
The top left panel shows that changes in value added in manufacturing are clearly reflected in both the Ifo series. The current situation generally tracks expectations fairly closely, with a lag. The trough for 6-month expectations in manufacturing was in December 2008, which was indeed about 6 months before the trough for the current situation series for manufacturing, although less than 6 months before the trough of value added in manufacturing in 2009Q1. We can say that employers were not surprised by the end of the recession, but without data on expectations further into the future than 6 months, we cannot tell what employers expected at the start of the recession, when layoff decisions had to be made. ${ }^{23}$

Examination of the preceding expansion proves more fruitful. As the boom began in 2005, the current situation and expectations in manufacturing initially rose together, but then expectations ceased to rise and remained much lower than the current situation until the recession hit. The only precedent for such a gap between the current situation and expectations is the unusual postunification boom, and the gap points to a lack of confidence on manufacturing employers' part that dovetails with the econometric evidence found above. There is a hint of a similar pattern for construction (top right panel), but expectations track the current situation closely throughout for retail and wholesale trade (bottom panels).

We can use the expectations data to quantify the role of expectations in hiring in the 200507 expansion. We focus on expectations and employment for the aggregate economy, since we cannot track true total employment in manufacturing in the boom, which would include temporary workers. Expectations refer to a change in the firm's fortunes, and because they fluctuate at high frequency, a one-quarter-differenced regression, with expectations themselves (EXP) in levels (converted to quarterly frequency by averaging), is the appropriate specification: ${ }^{24}$

$$
\Delta \log L_{t}=\emptyset_{0}+\emptyset_{1} \Delta \log \mathrm{GDP}_{t}+\emptyset_{2} \Delta \log w_{t}+\emptyset_{3} \mathrm{EXP}_{t-2}+\Delta \mu_{t}
$$

\footnotetext{
${ }^{23}$ We attempted to use data from the IAB-Betriebspanel on expected employment a year ahead, but these data proved unreliable.

${ }^{24}$ The expectations variable is neither differenced nor expressed in logs: expectations can have a zero value, and converting to an index involves arbitrariness.
} 
As table 8 shows, $\emptyset_{3}$ is positive and highly statistically significant, and the inclusion of the EXP variable increases the $R^{2}$ of the regression considerably. ${ }^{25}$

We next construct counterfactual expectations for the boom period based on the historical relationship between expectations and the current situation (CUR), to assess the extent to which pessimistic expectations dampened hiring. The fit is similar whether CUR enters in levels or in differences, and we construct counterfactual expectations for 2005Q3 onward using the coefficient from the following regression for the usual 1970-2003 period:

$$
\Delta \mathrm{EXP}_{t}=\rho_{0}+\rho_{1} \Delta \mathrm{CUR}_{t}+\Delta \xi_{t}
$$

We estimate $\hat{\rho}_{1}$ to be 0.61 . The counterfactual expectations during the 2003-05 boom are much higher than the actual expectations.

Table 9 summarizes the effect of the pessimistic expectations in the boom. Actual employment growth in the expansion was $3.7 \log$ points. Estimating equation 9 without controlling for expectations leads to the inaccurate prediction of a mere 1.4-log-point employment increase. Adding expectations to the specification significantly improves the accuracy of the prediction to a 3.2-log-point increase. The key is to know how much higher employment growth would have been predicted to be had expectations been higher: with counterfactual expectations, employment growth is predicted to be $4.1 \log$ points. The difference between the last two estimates shows the role of expectations: if expectations had behaved in the boom as they had historically, instead of having been unusually pessimistic, employment growth would have been $0.9 \log$ point higher. This confirms that employers hesitated to hire in the 2005-07 boom for lack of confidence that it would last and cognizant of the high firing costs in Germany; thus, when the recession they feared indeed arrived, they had less need to fire. The effect of this pessimism is sufficiently large to account for $0.9 / 1.6=56$ percent of the missing employment increase in the boom, and $0.9 / 3.9=23$ percent of the missing employment decline in the downturn.

\footnotetext{
${ }^{25}$ Surprisingly, the interactions of expectations with the other covariates have statistically insignificant coefficients, and so we do not include them.
} 
EVIDENCE FROM THE BUSINESS PRESS Our narrative characterizing the 2005-07 expansion as one of pessimistic expectations and unexpectedly low (conditional) employment growth is corroborated by our own survey of business cycle reporting by the leading daily German business newspaper, Handelsblatt, for the period 2005-09. Reports in the first 2 years of the expansion were remarkably downbeat, despite the fact that GDP growth was robust and (unconditional) employment growth unusually positive. A string of bad showings of the Ifo index of the overall business climate (a geometric average of the two indicators discussed above, namely, the current situation and expectations indices) established a relatively pessimistic outlook at the outset. ${ }^{26}$ The expansion was seen as driven by buoyant exports and not at all by internal demand (domestic investment and consumption). A commonly held view was that consumers were holding back spending in light of a continuing string of layoffs and restructuring measures by large firms, despite significant declines in the unemployment rate in 2005 heralded by major policymakers. ${ }^{27}$

The mood was further depressed by a general expectation that taxes - especially the valueadded tax-would be increased after the elections in fall 2005. Household income was seen as dented by flat wages, the Hartz reforms, and increases in social security contributions and energy prices. ${ }^{28}$ An expansion of consumer demand is thought to have kicked in only after the summer of 2006, when Germany hosted the World Cup soccer championship. ${ }^{29}$ Yet this view is not supported by the data; from 2005Q1 to 2006Q2, annualized real consumption growth averaged 0.5 percent, compared with 0.3 percent over the following 6 quarters. Even in July 2006 there was a perception that firms were not creating enough jobs despite a return to profitability and that the expansion would soon grind to a halt. ${ }^{30}$

\footnotetext{
26 "Wolken am europäischen Konjunkturhimmel" (Clouds on the European business cycle horizon), Handelsblatt, February 22, 2005; "Ifo spricht von chronischer Schwäche" (Ifo [Institute] cites chronic weakness), February 28, 2005; "Weniger Jobs trotz hoher Gewinne" (Fewer jobs despite higher profits), March 24, 2005. Journalist Olaf Storbeck noted that despite the conditions for a healthy expansion, consumers and employers were not cooperating: "1,2,3,4... Aufschwung!" (1,2,3,4...Boom!), April 25, 2005, and "Reformvorsprung für Deutschland" (A jump ahead with reforms for Germany), September 13, 2005.

27 "Clement sieht Arbeitslosigkeit auf Zenit" ([Economics Minister Wolfgang] Clement sees unemployment at its peak), March 31, 2005.

28 "Wirtschaft nimmt Fahrt auf—Konsum bleibt Hemmschuh" (The economy is taking off—consumer spending remains the bottleneck), November 15, 2005.

29 "Der kleine Luxus" (Small luxury), August 4, 2006.

30 "Der Aufwartstrend stockt" (The upward trend is sputtering), June 20, 2006; "Konzerne bauen in Deutschland ab" (Corporations are retrenching in Germany), July 18, 2006; "Die Jobwende bleibt aus" (The job turnaround isn't materializing), July 18, 2006. As late as summer 2006, Chancellor Angela Merkel criticized a series of high-profile
} 
By January 2007 the pessimistic mood had reversed completely, despite a 3 percent increase in the value-added tax which took effect that month. The first half of the year was characterized by remarkably positive news reporting, despite a perceived weak showing for the labor market. ${ }^{31}$ By summer 2007 the first signs were appearing that the slowdown in the United States had arrived in Germany, yet forecasts by the major economic research institutes warned of only modest spillovers, citing the effect of the reforms and shortages of skilled workers. ${ }^{32}$ Positive reports continued into the summer of 2008, and a survey of 500 managers of medium-size companies revealed that 76 percent believed they would not be affected by the ensuing economic crisis. ${ }^{33}$ By July 2008, however, the Ifo composite index had turned sharply downward, and by August the judgment was unanimous that the boom was over. ${ }^{34}$

Toward the end of the phase of negative growth (2008Q1-2009Q1), news reports began to suggest that employers were reluctant to fire workers, instead using short-time work and reducing working time balances and vacation to protect core workers. ${ }^{35}$ By July 2009, rising order books and recovery of the world economy contributed to a general recovery, which was mirrored in consumer optimism. ${ }^{36}$ By the end of 2009, the consensus view was that the recession was over.

layoffs by Allianz and Volkswagen: "Merkel ermahnt die Unternehmen" (Merkel admonishes businesses [for continuing layoffs]), August 24, 2006.

${ }^{31}$ See "Experten streiten über Aufschwung am Arbeitsmarkt" (Experts disagree over the boom for the labor market), August 2, 2007.

32 "Herbstgutachten Analyse: Neue Besen kehren gut" (Analysis of the fall [economic] forecasts: New brooms sweep well), October 17, 2007. The article "Ohne die USA mutig voraus" (Bravely forward without the United States), December 30, 2007, describes a strong positive sentiment that despite problems in the United States, export demand would continue and that firms were unlikely to lay off workers, given difficulties finding skilled workers.

33 "Deutsche Wirtschaft überraschend stark" (German economy is surprisingly strong), May 15, 2008; "Wirtschaft hat vielversprechend Pläne" (Promising outlook for the economy), June 4, 2008; "Finanzkrise? Kein Thema" (Financial crisis? Not an issue), June 7, 2008.

${ }^{34}$ See "Der Aufschwung ist vorbei" (The boom is over), August 14, 2008, which details the negative GDP growth results for the second quarter; "Ifo: "Abwärtstrend mit Riesenschritten" (Ifo: Negative trend with giant steps), September 24, 2008.

${ }^{35}$ In February, Handelsblatt reported that burgeoning working time account balances and administrative extension of short-time work had made machine tool producers well prepared for the crisis in comparison with previous recessions: "Erfahrene Zyklikler" (Experienced 'cyclists'), February 11, 2009. In particular, mention is made of businesses holding onto trained personnel as long as possible; see "Trotz Krise gibt es sie- die Jobwunder" (Despite the crisisthere are job miracles), March 4, 2009.

36 "Die Industrie meldet sich zurück" (Industry is back), July 7, 2009; "Deutsche Tugend" (German virtues), September 2, 2009; "Deutsches Mini-Jobwunder macht Hoffnung" (German mini-job miracle creates hope), October 15, 2009. For a note on consumer sentiment, see "Verkehrte Welt" (Topsy-turvy world), October 8, 2009. 


\section{IV.F. Competing and Complementary Explanations of the Labor Market Miracle}

We can explain about 60 percent of the labor market miracle in Germany with wage moderation and slow employment growth in the previous boom. Only about half of the latter can be attributed to pessimistic employer expectations, however. Christine Franz and Steffen Lehndorff (2010) hypothesize that layoffs were low in the recession because working time accounts had reduced the long-run marginal cost of an extra hour per worker, leading to a permanent increase in hours per worker at the expense of employment. ${ }^{37}$ To assess the possible magnitude of this effect, we compute difference-in-differences comparing changes in hours per worker in 1996-2004, when they were still falling rapidly, and 2004-07, when they leveled out. Before 1996, reductions in hours per worker were associated with reductions in usual hours for full-time workers and appear to reflect the success of unions in translating increased wealth into increased leisure. ${ }^{38}$ Table 10 shows that the regime change between 1996-2004 and 2004-07 was driven by a slowing increase in the share of workers working part-time and rising standard weekly hours. Even though we chose the dates so as to maximize the buildup of working time accounts in the expansion, we find that their overall contribution appears small. However, estimates of working time accounts may not be reliable, especially when standard weekly hours are changing, and so part of the low hiring in the expansion could well be due to a permanent shift in hours conditional on GDP and labor costs.

The model presented at the beginning of this section would attribute the remaining 40 percent of the miracle to a regime shift, that is, changing model parameters that would increase the quasi-fixity of labor. We have focused on working time accounts and the disincentives they create for layoffs, yet a number of alternative explanations can also be explored in light of our empirical findings and the predictions of the model. An explanation frequently cited for the low employment growth in the 2005-07 expansion is a higher incidence of skilled worker "shortages" (inability to hire) than in previous expansions, or a reluctance to lay off workers when the recession arrived, fearing difficulties in rehiring them in the recovery. ${ }^{39}$ Although firms reporting shortages in the boom were not less likely to lay off in the recession (Klinger and others 2011), and although the vacancies-to-employment ratio and the share of firms reporting shortages were similar in the 2005-

\footnotetext{
${ }^{37}$ In terms of the model in section IV.A, this is a decrease in the parameter $\eta_{\Omega \theta}$.

${ }^{38}$ See Hunt (1998), Alesina, Glaeser, and Sacerdote (2005), and Burda, Hamermesh, and Weil (2008).

${ }^{39}$ Sachverständigenrat (2010), Schaz and Spitznagel (2010), Schütt (2010). In the business press, this factor was mentioned frequently after the onset of the Great Recession.
} 
07 expansion and in its predecessor (Gartner and Klinger 2010), it is possible that increasing specialization of the workforce and slow labor force growth have made firms more reluctant to part with their skilled workers in recessions. ${ }^{40}$

An explanation that competes with pessimistic employer expectations is that outputconstrained firms experienced a positive productivity shock at the beginning of the expansion. ${ }^{41} \mathrm{~A}$ priori, this would seem less plausible for Germany, an open economy facing a competitive international market. Under these conditions, a productivity shock would more likely be represented as a fall, not a rise in prices. In any case, comparison of labor productivity (output per hour) across expansions shows that whereas output increased in 2005-07 by an amount to similar to that in the previous three booms, labor productivity rose by not much more than half of the corresponding value. There is no evidence that this mechanism was responsible for the sluggish expansion. $^{42}$

\section{Conclusion}

Like the United States, Germany suffered its worst postwar recession in 2008-09. Yet employment barely fell and unemployment hardly rose. Germany generally accommodates reductions in labor demand more along the intensive margin than does the United States, and we have shown that the large reductions in hours per worker in Germany were largely consistent with the magnitude of the recession and recent wage moderation. The lack of a decline in employment was a historical anomaly, however. One partial explanation for the "labor market miracle" is pessimistic expectations leading to low hiring in the previous expansion, with the result that fewer workers were laid off when the recession arrived. Weak employment growth in the boom accounts for 41 percent of the missing employment decline in the recession. Our account is thus broadly consistent with the narrative in the business press.

\footnotetext{
${ }^{40}$ In terms of the model in section IV.A, this would correspond to an increase in the parameter $c$.

${ }^{41}$ A firm that cannot sell more of its output at the given price will react to an exogenous increase in productivity by cutting labor (or hiring less).

${ }^{42}$ Using the recessions defined in table 3, output increased in 2005-07 boom by $6.2 \log$ points (versus $6.6 \log$ points in the three previous recessions), but output per hour increased by only $3.8 \log$ points (6.8 log points in the three previous recessions).
} 
Although part of Germany's labor market response to the Great Recession is directly related to expectations, another component is related to changes in labor market institutions since the mid1990s. The increased use of privately negotiated working time accounts appears to have cheapened private adjustment along the intensive margin and substituted for the more traditional government short-time work - a potentially interesting lesson for the United States. However, incentives inherent in the working time accounts, which allow employers to avoid the overtime premium in good times, are likely to have reduced layoffs in the recession. For any desired change in total hours, lower sensitivity of costs of hours per worker also increased the effective cost of layoffs. Thus, while the change in hours per worker in the recession was not unusual, the unexpected development was the larger number of workers able to retain their job and experience this decline in hours per worker.

Although it may be tempting to consider working time accounts for the United States, it is important to be circumspect when comparing labor markets across countries. Their functioning is conditioned by the system of labor relations and their interaction with the whole spectrum of labor market institutions. It is noteworthy that working time accounts in Germany are more prevalent in large firms, which have more resources to manage the complex task of human resources planning, and which are overseen by works councils. 


\section{Appendix: A model of dynamic labor demand with intensive and extensive margins ${ }^{43}$}

\section{Model setup}

The representative firm faces exogenous sequences of relative output price $\left\{P_{t}\right\}$ and standard hourly wages $\left\{W_{t}\right\} .{ }^{44}$ At $t=0$, it chooses a plan of employment $\left\{L_{t}\right\}$ (the extensive margin), and hours per worker $\left\{\theta_{t}\right\}$ (the intensive margin) to maximize expected discounted profits:

$$
\max _{\left.\left\{L_{t}\right\}, \theta_{t}\right\}} E_{0} \sum_{t=0}^{\infty} \beta^{t}\left[P_{t} Y_{t}-W_{t} \Omega\left(\theta_{t}\right) L_{t} \theta_{t}-\Phi L_{t}-\frac{c}{2}\left(L_{t}-L_{t-1}\right)^{2}\right]
$$

subject to a neoclassical production function of hours worked $\left(H_{\mathrm{t}}\right)$ :

$$
Y_{t}=f\left(H_{t}\right)=f\left(L_{t} \theta_{t}\right)
$$

with $f^{\prime}>0, f^{\prime \prime}<0$. The deterministic discount factor is denoted by $\beta$ with $0<\beta<1$. The function $\Omega\left(\theta_{t}\right)$ returns the average markup on the standard hourly wage $W_{\mathrm{t}}$ is paid when employees work $\theta_{\mathrm{t}}$ hours, reflecting rising costs per hour at the intensive margin (meaning that $\Omega\left(\theta_{t}\right) \geq 1, \Omega^{\prime}>0, \Omega^{\prime \prime}>0$ for all $\theta_{\mathrm{t}}$ ). The elasticity of $\Omega$ with respect to $\theta, \eta_{\Omega \theta}$, is assumed constant. In addition to variable labor costs $W_{t} \Omega\left(\theta_{t}\right) \theta_{t} L_{t}$, firms also pay a fixed charge $\Phi$ per employee which reflect social security contributions and related fixed labor costs.

The first order necessary conditions for an optimum are:

$$
\begin{array}{ll}
L_{t} \text { (bodies): } & \theta_{t}\left(P_{t} f^{\prime}-\Omega W_{t}\right)-\Phi-c\left(L_{t}-L_{t-1}\right)+\beta c\left(\mathrm{E}_{t} L_{t+1}-L_{t}\right)=0 \\
\theta_{t} \text { (hours/worker): } & \left(P_{t} f^{\prime}-\Omega W_{t}-\theta_{t} \Omega^{\prime} W_{t}\right) L_{t}=0
\end{array}
$$

Since $L_{\mathrm{t}}>0$, we can write (A2), using the definition of $\eta_{\Omega \theta}$, as

$$
P_{t} f^{\prime}=\left(1+\eta_{\Omega \theta}\right) \Omega W_{t}
$$

(A1) and (A3) can be combined to obtain

$$
\theta_{t} \eta_{\Omega \theta} \Omega W_{t}=\Phi+c\left(L_{t}-L_{t-1}\right)-\beta c\left(\mathrm{E}_{t} L_{t+1}-L_{t}\right) .
$$

\section{Steady state}

In the steady state, $P_{\mathrm{t}}=P, W_{\mathrm{t}}=W, L_{\mathrm{t}}=L, \theta_{\mathrm{t}}=\theta$, etc. Two equations govern the extensive and intensive labor margins, keeping in mind that $\Omega=\Omega(\theta)$ and $f^{\prime}=f^{\prime}(\theta L)$ :

$$
\begin{aligned}
& \theta\left(P f^{\prime}-\Omega W\right)=\Phi \\
& P f^{\prime}=W \Omega\left(1+\eta_{\Omega \theta}\right)
\end{aligned}
$$

which can be rewritten as:

$$
\begin{aligned}
& W \Omega \eta_{\Omega \theta}=\frac{\Phi}{\theta} \\
& \frac{P f^{\prime}-W \Omega}{W \Omega}=\eta_{\Omega \theta}
\end{aligned}
$$

\footnotetext{
${ }^{43}$ Patrick Bunk provided research assistance in constructing this appendix.

${ }^{44}$ The price level is normalized to one, so all prices are in real terms. This partial equilibrium perspective is solely for expositional purposes. A more complete model would address feedback effects from labor and product markets in general equilibrium. Because the model is especially relevant for the manufacturing sector, we think this is the right model in this context.
} 
The model dichotomizes in the following sense: given $W, \Phi, \eta_{\Omega \theta}$, and $\Omega($.$) , steady-state hours per$ worker $\theta$ is given by (A7). Given $\theta$ and $P$, (A8) determines $L$ and thus $H$.

\section{Log-linearized approximation}

Denote the percentage deviation of $X_{t}$ around $X$ by $\hat{X}_{t}$. The log-linearization of the first-order conditions plus the definition of effective hours $\left(H_{t}=L_{t} \theta_{t}\right)$ yields three equations in three unknowns, $\hat{L}_{t}, \hat{\theta}_{t}$ and $\hat{H}_{t}$ :

$$
\begin{aligned}
& \left(1+\eta_{\Omega \theta}\right) \hat{\theta}_{t}+\hat{W}_{t}=\frac{c L}{\Phi}\left(\hat{L}_{t}-\hat{L}_{t-1}\right)-\frac{\beta c L}{\Phi}\left(\mathrm{E}_{t} \hat{L}_{t+1}-\hat{L}_{t}\right) \\
& \eta_{\Omega \theta} \hat{\theta}_{t}+\eta_{f^{\prime} H} \hat{H}_{t}=-\hat{W}_{t}+\hat{P}_{t} \\
& \hat{H}_{t}=\hat{\theta}_{t}+\hat{L}_{t}
\end{aligned}
$$

where $\eta_{f^{\prime} H}=-\frac{H f^{\prime \prime}(H)}{f^{\prime}(H)}$ is the elasticity of the marginal product of hours evaluated at steadystate, which we assume to be less than one. Conditioning on total hours, an increase in the real product wage reduces use of the intensive margin, and has an ambiguous effect on employees. (A10) and (A11) imply:

$$
\hat{\theta}_{t}=-\frac{\eta_{f^{\prime} H}}{\eta_{\Omega \theta}+\eta_{f^{\prime} H}} \hat{L}_{t}-\frac{1}{\eta_{\Omega \theta}+\eta_{f^{\prime} H}}\left(\hat{W}_{t}-\hat{P}_{t}\right)
$$

which substituted in (A9) and rearranged yields

$$
\varphi_{W}\left(\hat{W}_{t}-\hat{P}_{t}\right)-\varphi_{P} \hat{P}_{t}=\mathrm{E}_{t} \hat{L}_{t+1}-A \hat{L}_{t}+B \hat{L}_{t-1}
$$

with

$$
\varphi_{W}=\frac{\Phi}{\beta c L}\left(\frac{1-\eta_{f^{\prime} H}}{\eta_{\Omega \theta}+\eta_{f^{\prime} H}}\right), \quad \varphi_{P}=\frac{\Phi}{\beta c L}, A=\left[\frac{\Phi\left(1+\eta_{\Omega \theta}\right) \eta_{f^{\prime} H}}{\beta c L\left(\eta_{\Omega \theta}+\eta_{f^{\prime} H}\right)}+\frac{1}{\beta}+1\right], \text { and } B=\beta^{-1} \text {. }
$$

The method of factorization ${ }^{45}$ can be used to find the stable solution of (A13) expressing current employment $\hat{L}_{t}$ as a function of lagged employment and current and expected future values of output prices and hourly base wage rates:

$$
\hat{L}_{t}=\lambda \hat{L}_{t-1}+\sum_{\tau=0}^{\infty}(\lambda \beta)^{\tau} \mathrm{E}_{t}\left[\varphi_{P} \hat{P}_{t}-\varphi_{W}\left(\hat{W}_{t}-\hat{P}_{t}\right)\right]
$$

where $\lambda$ denotes the stable root of the difference equation (A14). Equations (A14) and (A12) summarize the firm's optimal of intensive and extensive margins, respectively, and appear as equations (8) and (9) in the main text, with $\eta_{\theta \mathrm{L}}=\eta_{f^{\prime} H} /\left(\eta_{\Omega \theta}+\eta_{f^{\prime} H}\right)$ and $\eta_{\theta W}=1 /\left(\eta_{\Omega \theta}+\eta_{f^{\prime} H}\right)$.

The dependence of $\lambda$ on the cost of adjustment parameter $c$ and the elasticity of the wage to the extensive margin $\eta_{\Omega \theta}$

To study the effect of $c$ and $\eta_{\Omega \theta}$ on the persistence parameter $\lambda$, we differentiate the quadratic equation which determines $\lambda$, i.e.

\footnotetext{
${ }^{45}$ Sargent (1987, p.183-4)). A more detailed technical derivation is available from the authors on request.
} 


$$
\lambda^{2}-\left[\frac{\Phi}{\beta c L} \frac{\left(1+\eta_{\Omega \theta}\right) \eta_{f^{\prime} H}}{\eta_{\Omega \theta}+\eta_{f^{\prime} H}}+\frac{1}{\beta}+1\right] \lambda+\beta^{-1}=0,
$$

with respect to $\eta_{\Omega \theta}$ and solve:

$$
\frac{d \lambda}{d \eta_{\Omega \theta}}=\frac{\lambda \frac{\Phi \eta_{f^{\prime} H}}{\beta c L}\left[\frac{\eta_{\Omega \theta}\left(1-\eta_{f^{\prime} H}\right)}{\left(\eta_{\Omega \theta}+\eta_{f^{\prime} H}\right)^{2}}\right]}{2 \lambda-\frac{\Phi}{\beta c L} \frac{\left(1+\eta_{\Omega \theta}\right) \eta_{f^{\prime} H}}{\eta_{\Omega \theta}+\eta_{f^{\prime} H}}+\frac{1}{\beta}+1} .
$$

The denominator is unambiguously negative, since $0<\lambda<1$. The numerator is positive as long as $\eta_{f^{\prime} H}<1$. Thus $\mathrm{d} \lambda / \mathrm{d} \eta_{\Omega \theta}<0$. A decrease in the elasticity of hourly wage with respect to the intensive margin increases the persistence of employment.

The effect of the adjustment cost parameter $c$ on persistence $\lambda$ is given by:

$$
\frac{d \lambda}{d c}=-\frac{\lambda \frac{\Phi}{\beta c^{2} L} \frac{\left(1+\eta_{\Omega \theta}\right) \eta_{f^{\prime} H}}{\eta_{\Omega \theta}+\eta_{f^{\prime} H}}}{2 \lambda-\frac{\Phi}{\beta c L} \frac{\left(1+\eta_{\Omega \theta}\right) \eta_{f^{\prime} H}}{\eta_{\Omega \theta}+\eta_{f^{\prime} H}}-\frac{1}{\beta}-1} .
$$

This expression is always positive; an increase in $c$ increases persistence and increases the weights placed on future expectations in (A15). Higher values of $\lambda$ imply that temporary changes in current demand (proxied by $P$ ) or product wages $(W / P)$ have a smaller effect on current employment, all other things equal. 


\section{References}

Abraham, Katharine G., and Susan N. Houseman. 1993. Job Security in America: Lessons from Germany. Brookings.

Akerlof, George A., Andrew K. Rose, Janet L. Yellen, and Helga Hessenius. 1991. "East Germany in from the Cold: The Economic Aftermath of Currency Union." Brookings Papers on Economic Activity, no. 1: 1-87.

Alesina, Alberto, Edward Glaeser, and Bruce Sacerdote. 2005. "Work and Leisure in the United States and Europe: Why So Different?” NBER Macroeconomics Annual 2005 1-64.

Boeri, Tito, and Herbert Bruecker. 2011. "Short-Time Work Benefits Revisited: Some Lessons from the Great Recession.” Institute for the Study of Labor Discussion Paper 5635 (April). Bonn: IZA.

Bogedan, Claudia, Wolfram Brehmer, and Alexander Herzog-Stein. 2009. "Betriebliche Beschäftigungssicherung in der Krise: Eine Kurzauswertung der WSIBetriebsrätebefragung 2009.” Düsseldorf: Wirtschafts- und Sozialwissenschaftliches Institut in der Hans-Böckler-Stiftung (December).

Boysen-Hogrefe, Jens, and Dominik Groll. 2010. "The German Labour Market Miracle." National Institute Economic Review 214, no. 1: R38-R50.

Bundesagentur für Arbeit. 2011. "Der Arbeitsmarkt in Deutschland: Zeitarbeit in Deutschland Aktuelle Entwicklungen." Arbeitsmarktberichterstattung (January).

Bundesarbeitsgericht. 2007. "Urteil vom 8.11.2007, 2 AZR 418/06 Betriebsbedingte Kündigung aus Witterungsgründen". juris.bundesarbeitsgericht.de/cgi-bin/rechtsprechung/document.py? Gericht=bag\&Art $=$ en\&sid=47d5a35b9cef6b6f92baf2ca255a9ec8\&nr=12524\&pos=7\&anz $=$ 33, accessed March 4, 2011.

Burda, Michael C., and Michael Kvasnicka. 2006. "Zeitarbeit in Deutschland: Trends und Perspectiven." Perspektiven der Wirtschaftspolitik 7, no. 2:195-225.

Burda, Michael C., and Mark Weder. 2010. "Payroll Taxes, Social Insurance and Business Cycles." CEPR Discussion Paper 7984. September. London: Centre for Economic Policy Research.

Burda, Michael C., Daniel S. Hamermesh, and Philippe Weil. 2008. "The Distribution of Total Work in the EU and USA." In Working Hours and Job Sharing in the EU and USA: Are Europeans Lazy? Or Americans Crazy? edited by Tito Boeri, Michael C. Burda, and Francis Kramarz. Oxford University Press.

Carlin, Wendy, and David Soskice. 2009. "German Economic Performance: Disentangling the Role of Supply-Side Reforms, Macroeconomic Policy and Coordinated Economy Institutions." Socio-Economic Review 7, no. 1:67-99.

Cooley, Thomas F., ed. 1995. Frontiers of Business Cycle Research. Princeton University Press.

Dustmann, Christian, Johannes Ludsteck, and Uta Schönberg. 2009. "Revisiting the German Wage Stucture.” Quarterly Journal of Economics 124, no. 2: 843-81.

Ellguth, Peter, and Susanne Kohaut. 2009. "Tarifbindung und betriebliche Interessenvertretung in Ost und West: Schwund unterm sicheren Dach." IAB Forum 2:68-75.

Elsby, Michael W. L., Bart Hobijn, and Ayşegül Şahin. 2010. "The Labor Market in the Great Recession." Brookings Papers on Economic Activity, no. 1: 1-48. 
Fahr, René, and Uwe Sunde. 2009. "Did the Hartz Reforms Speed up the Matching Process? A Macro-Evaluation Using Empirical Matching Functions." German Economic Review 10, no. 3: 284-316.

Farber, Henry S. 2010. "Job Loss and Unemployment in the 21st Century: The Great Recession in Labor Market Perspective." Princeton University (November).

Franz, Christine, and Steffen Lehndorff. 2010. "Arbeitszeitentwicklung und Krise - eine Zwischenbilanz." IAQ-Report: Aktuelle Forschungsergebnisse aus dem Institut Arbeit und Qualifikation 7: 1-12.

Galí, Jordi, and Thijs van Rens. 2010. "The Vanishing Procyclicality of Labor Productivity." Institute for the Study of Labor Discussion Paper 5099. Bonn: IZA.

Gartner, Hermann, and Sabine Klinger. 2010. "Verbesserte Institutionen für den Arbeitsmarkt in der Wirtschaftskrise." Wirtschaftsdienst 90, no. 11: 728-34.

Gordon, Robert J. 2010. "Okun's Law and Productivity Innovations." American Economic Review: Papers and Proceedings 100, no. 2: 11-15.

Gross, Hermann, and Michael Schwarz. 2007. "Betriebs- und Arbeitszeiten 2005: Ergebnisse einer repräsentativen Betriebsbefragung." Beiträge aus der Forschung: Sozialforschungsstelle Dortmund 153: 1-174.

Hamermesh, Daniel S. 1989. "Labor Demand and the Structure of Adjustment Costs." American Economic Review 79, no. 4: 674-89.

Hamermesh, Daniel S., and Gerard A. Pfann. 1996. "Adjustment Costs in Factor Demand.” Journal of Economic Literature 34, no. 3: 1264-92.

Herzog-Stein, Alexander, and Hartmut Seifert. 2010. "Der Arbeitsmarkt in der Großen Rezession Bewährte Strategien in neuen Formen." WSI-Mitteilungen 11: 551-59.

Herzog-Stein, Alexander, Fabian Lindner, Simon Sturn, and Till van Treeck. 2010. "Vom Krisenherd zum Wunderwerk? Der deutsche Arbeitsmarkt im Wandel.” Institut für Makroökonomie und Konjunkturforschung Report 56: 1-18.

Hoff, Andreas. 2009. "Arbeitszeit-Korridor statt Kurzarbeit.” Personalmagazin 9: 54-56.

Hunt, Jennifer. 1998. "Hours Reductions as Work-Sharing." Brookings Papers on Economic Activity, no. $1: 339-69$.

1999. "Has Work-Sharing Worked in Germany?" Quarterly Journal of Economics 114, no. 1: 117-48.

Khan, Aubhik, and Julia K. Thomas. 2003. "Nonconvex Factor Adjustments in Equilibrium Business Cycle Models: Do Nonlinearities Matter?" Journal of Monetary Economics 50, no. 2: 33160.

Klinger, Sabine, and Thomas Rothe. 2010. "The Impact of Labour Market Reforms and Economic Performance on the Matching of Short-Term and Long-Term Unemployed." IAB Discussion Paper no. 13/2010. Nürnberg: Institut für Arbeitsmarkt- und Berufsforschung.

Klinger, Sabine, Martina Rebien, Markus Heckmann, and Jörg Szameitat. 2011. "Did Recruitment Problems Account for the German Job Miracle?" International Review of Business Research Papers 7, no. 1: 265-81.

Klös, Hans-Peter, and Holger Schäfer. 2010. "Krisenmanagement über Variationen des Arbeitsvolumens?" Arbeit 2-3: 132-46.

Lesch, Hagan. 2010. "Lohnpolitik 2000 bis 2009: Ein informelles Bündnis für Arbeit." IW-Trends: Vierteljahresschrift zur empirischen Wirtschaftsforschung 37, no. 1: 1-15. 
Logeay, Camille, and Rudolf Zwiener. 2008. "Deutliche Realeinkommensverluste für Arbeitnehmer: Die neue Dimension eines Aufschwungs." WSI Mitteilungen 8: 415-22.

Möller, Joachim. 2010. "The German Labor Market Response in the World Recession - Demystifying a Miracle." Zeitschrift für Arbeitsmarktforschung 42, no. 4: 325-36.

Ochel, Wolfgang. 2005. "Hartz IV- Welfare to Work in Germany." CESifo DICE Report 2: 18-25.

Okun, Arthur. 1962. "Potential GNP: Its Measurement and Significance." American Statistical Association, Proceedings of the Business and Economics Statistics Section 98-104.

OECD (Organisation for Economic Co-operation and Development). 2010a. Employment Outlook 2010: Moving Beyond the Jobs Crisis. Paris.

. 2010b. Economic Survey of Germany 2010: The Banking System: Lessons from the Financial Crisis. Paris.

Peichl, Andreas, and Sebastian Siegloch. 2010. "Incorporating Labor Demand Effects into the Microsimulation of Tax and Benefit Reforms." Bonn: IZA (January).

Sachverständigenrat zur Begutachtung der gesamtwirtschaftlichen Entwicklung. 2010. Jahresgutachten 2009/10: Die Zukunft nicht aufs Spiel setzen. Paderborn: Bonifatius.

Sargent, Thomas J. 1978. "Estimation of Dynamic Labor Demand Schedules under Rational Expectations." Journal of Political Economy 86, no. 6: 1009-44.

Schaz, Philipp, and Eugen Spitznagel. 2010. "Makroökonomische Dynamik von Arbeitsmärkten : Ein Vergleich interner und externer Flexibilitäten in den USA und in Deutschland." WSIMitteilungen 12: 626-35.

Schneider, Stefan, and Bernhard Graef. 2010. "Germany's Jobs Miracle: Short-Time Work, Flexible Labour Contracts and Healthy Companies.” Deutsche Bank Research Briefing. Frankfurt: Deutsche Bank (April 27).

Schütt, Petra. 2010. "Fachkräfte finden, binden und entwickeln." Arbeit 2-3: 178-94.

Seifert. Hartmut. 2004. "Flexibility through Working Time Accounts: Reconciling Economic Efficiency and Individual Time Requirements," WSI Discussion Paper 130. Düsseldorf: Wirtschafts- und Sozialwissenschaftliches Institut in der Hans-Böckler-Stiftung (August).

Sinn, Hans-Werner. 1999. "International Implications of German Unification." In The Economics of Globalization: Policy Perspectives from Public Economics, edited by Assaf Razin and Efraim Sadka. Cambridge University Press. 2005. Ist Deutschland noch zu retten? Berlin: Ullstein Buchverlage.

Treadway, Arthur B. 1970. "Adjustment Costs and Variable Inputs in the Theory of the Competitive Firm." Journal of Economic Theory 2, no. 4: 329-47.

U.S. Bureau of Labor Statistics. 2010. "International Comparisons of GDP per Capita and per Hour, 1960-2009." www.bls.gov/fls/intl_gdp capita gdp hour.htm, accessed February 23, 2011.

Will, Henner. 2010. "Kurzarbeit als Flexibilisierungsinstrument: Hemmnis strukturellen Wandels oder konjunkturelle Brücke für Beschäftigung?” Institut für Makroökonomie und Konjunkturforschung Study 5: 1-92.

Zapf, Ines, and Wolfram Brehmer. 2010. "Arbeitszeitkonten haben sich bewährt." IAB Kurzbericht 22: $1-8$. 
Table 1. Changes in output and labor market measures in the Great Recession

\begin{tabular}{|lcccccc|}
\hline & \multicolumn{3}{c}{ United States } & \multicolumn{3}{c|}{ Germany } \\
& Peak & Trough & Change & Peak & Trough & Change \\
\hline Output & Q4 2007 & Q2 2009 & -4.1 & Q1 2008 & Q1 2009 & -6.6 \\
Unemployment rate & Q1 2007 & Q4 2009 & 5.5 & Q4 2008 & Q2 2009 & 0.5 \\
Employment & Q1 2008 & Q4 2009 & -5.6 & Q4 2008 & Q2 2009 & -0.5 \\
Person-hours & Q4 2007 & Q4 2009 & -7.6 & Q2 2008 & Q2 2009 & -3.4 \\
\hline
\end{tabular}

Note: Changes are expressed in \% for output, employment and hours, and percentage points for the unemployment rate. All are seasonally adjusted, and output is real GDP.

Source: GDP: Bureau of Economic Analysis, Federal Statistical Office; unemployment and employment: comparable data from the Bureau of Labor Statistics; person-hours: Bart Hobijn estimates of total nonfarm hours, Federal Statistical Office. 
Table 2. Accounting for output in the Great Recession 2008-2010

\begin{tabular}{|ccccccc|}
\hline & Output & Productivity & $\begin{array}{l}\text { Person- } \\
\text { hours }\end{array}$ & Hours/worker & Workers/LF & Labor force \\
& $\begin{array}{c}\Delta \mathrm{Y} / \mathrm{Y} \\
(1)\end{array}$ & $\begin{array}{c}\Delta(\mathrm{Y} / \mathrm{H}) /(\mathrm{Y} / \mathrm{H}) \\
(2)\end{array}$ & $\begin{array}{c}\Delta \mathrm{H} / \mathrm{H} \\
(3)\end{array}$ & $\begin{array}{c}\Delta(\mathrm{H} / \mathrm{L}) /(\mathrm{H} / \mathrm{L}) \\
(4)\end{array}$ & $\begin{array}{c}\Delta(\mathrm{L} / \mathrm{LF}) /(\mathrm{L} / \mathrm{LF}) \\
(5)\end{array}$ & $\begin{array}{c}\Delta \mathrm{LF} / \mathrm{LF} \\
(6)\end{array}$ \\
\hline $\begin{array}{c}\text { United States } \\
\text { Q4 2007- }\end{array}$ & -4.2 & +2.5 & -6.7 & -2.1 & -5.3 & +0.7 \\
$\begin{array}{l}\text { Q2 2009 } \\
\text { Q1 2008- }\end{array}$ & -2.4 & +6.0 & -8.4 & -2.2 & -6.1 & -0.1 \\
Q4 2009 & & & & & & \\
\hline $\begin{array}{c}\text { Germany } \\
\text { Q1 2008- }\end{array}$ & -6.8 & -4.0 & -2.9 & -3.3 & +0.4 & +0.1 \\
Q1 2009 & & -3.0 & -2.4 & -2.6 & +0.4 & -0.2 \\
Q1 2008- & -5.4 & -3.0 & & & \\
Q4 2009 & & & & & & \\
\hline
\end{tabular}

Note: Units are log points (approximately percent changes). Columns 2 and 3 sum to column 1, and columns 4, 5 and 6 sum to column 3. For the United States, column 2 refers to non-farm business and column 4 to the private sector only, so columns 3 and 5 obey the identity by construction. German figures may not add due to rounding.

Sources: Germany: Federal Statistical Office; U.S. GDP: Bureau of Economic Analysis; U.S. employment: Bureau of Labor Statistics CPS series from international comparative tables; U.S. hours per worker: Bureau of Labor Statistics series CES0500000002; U.S. productivity: Bureau of Labor Statistics series PRS85006093; labor force: Civilian labor force BLS series LNS11000000Q. Authors' calculations: log differentiation of change in output. 


\section{Table 3: Decomposition of German person-hours reductions into employment and hours per worker}

\begin{tabular}{|ccccc|}
\hline Recession & $\Delta$ person-hours & $\Delta$ employment & $\Delta$ hours per worker & $\begin{array}{c}\text { Percent of adjustment } \\
\text { in hours per worker } \\
\end{array}$ \\
& $(1)$ & $(2)$ & $(3)$ & $(4)$ \\
\hline $1973-1975$ & -7.9 & -3.4 & -4.5 & 57 \\
& $(-4.4)$ & $(-2.6)$ & $(-1.8)$ & $(41)$ \\
$1979-1982$ & -4.1 & -0.2 & -3.9 & 94 \\
& $(-2.7)$ & $(-1.5)$ & $(-1.2)$ & $(44)$ \\
$1991-1993$ & -4.4 & -4.0 & -0.4 & 9 \\
& $(-3.1)$ & $(-4.0)$ & $(+0.9)$ & $(-29)$ \\
$2001-2005$ & -3.6 & -1.5 & -2.2 & 60 \\
& $(-2.1)$ & $(-2.2)$ & $(+0.1)$ & $(-5)$ \\
$2008-2009$ & -3.3 & 0.2 & -3.5 & 106 \\
& $(-3.6$ & $(-0.8)$ & $(-2.8)$ & $(78)$ \\
\hline
\end{tabular}

Note: Quarterly, seasonally adjusted data. Units are log points (approximately percent changes). Figures in parentheses refer to counterparts in HP-detrended data $(\lambda=1600)$. Recession dates are taken from the Sachverständigenrat (Council of Economic Advisors) (2010): Q2 1973-Q2 1975, Q4 1979-Q4 1982, Q1 1991-Q3 1993, Q1 2001-Q2 2005, Q1 2008-Q2 2009. The units in columns 1-3 are log points (approximately percent changes); column 4 is in percent. Columns 2 and 3 may not add up to column 1 due to rounding.

Source: Federal Statistical Office, authors' calculations: log differentiation of change in personhours. 
Table 4: Correlates of hours per worker and employment

\begin{tabular}{|lcccc|}
\hline & \multicolumn{2}{c}{ Hours per worker } & \multicolumn{2}{c|}{ Employment } \\
& $\Delta \mathrm{H} / \mathrm{L}$ & $\Delta \mathrm{H} / \mathrm{L}$ & $\mathrm{L}_{\mathrm{t}}$ & $\Delta \mathrm{L}$ \\
& $(1)$ & $(2)$ & $(3)$ & $(4)$ \\
\hline$\Delta$ GDP & 0.18 & 0.17 & -- & 0.18 \\
& $(0.05)$ & $(0.05)$ & & $(0.05)$ \\
$\Delta$ Labor costs per & 0.09 & 0.13 & -- & -0.05 \\
worker & $(0.05)$ & $(0.05)$ & & $(0.04)$ \\
Hours per worker ${ }_{\mathrm{t}-1}$ & -- & -0.07 & -- & -0.09 \\
& & $(0.02)$ & & $(0.04)$ \\
GDP $_{\mathrm{t}-1}$ & -- & -0.03 & 0.69 & 0.05 \\
& & $(0.01)$ & $(0.06)$ & $(0.02)$ \\
Labor cost per & -- & 0.01 & -0.51 & -0.05 \\
worker & & $(0.01)$ & $(0.04)$ & $(0.02)$ \\
Trend & -- & -- & -0.0035 & -- \\
& & & $(0.0011)$ & \\
Constant & -0.0036 & 0.4118 & 18.4279 & 1.0784 \\
& $(0.0004)$ & $(0.2003)$ & $(2.0600)$ & $(0.4663)$ \\
\hline $\mathrm{R}^{2}$ & 0.23 & 0.31 & 0.97 & 0.25 \\
Observations & 135 & 135 & 135 & 135 \\
\hline
\end{tabular}

Note: All variables are in logs except the trend. Newey-West standard errors based on four lags in parentheses. Quarterly, seasonally adjusted data from 1970-2003. Labor costs are adjusted for reimbursements for short-time payments and short time-related social security payments. 
Table 5: Sources of unexpected employment changes

\begin{tabular}{|c|c|c|c|c|c|c|}
\hline & \multicolumn{3}{|c|}{ Employment change } & \multicolumn{2}{|c|}{ Value added change $\mathrm{t}-1$} & \multirow{2}{*}{$\begin{array}{c}\text { Sum } \\
\text { weighted } \\
\text { residuals } \\
\Sigma_{\mathrm{j}} \beta_{\mathrm{j}} \Delta \hat{\varepsilon}_{\mathrm{it-j}} \\
\quad(6) \\
\end{array}$} \\
\hline & $\begin{array}{c}\text { Actual } \\
\Delta \mathrm{L}_{\mathrm{i}} \\
(1)\end{array}$ & $\begin{array}{l}\text { Predicted } \\
\Delta \widehat{L}_{\mathrm{i}} \mid \mathrm{V}_{\mathrm{i}, \mathrm{W}} \\
\quad(2)\end{array}$ & $\begin{array}{c}\text { Residual } \\
\qquad \Delta \hat{\eta}_{\text {it }} \\
(3)\end{array}$ & $\begin{array}{c}\text { Actual } \\
\Delta \mathrm{V}_{\mathrm{it}-1} \\
(4)\end{array}$ & $\begin{array}{c}\text { Predicted } \\
\Delta \widehat{V}_{\mathrm{it}-1} \mid \mathrm{GDP}_{\mathrm{t}-1} \\
\quad \text { (5) }\end{array}$ & \\
\hline \multicolumn{7}{|l|}{ A. Recession } \\
\hline All industries & -0.002 & -0.042 & 0.039 & -- & -- & -- \\
\hline Manufacturing & -0.038 & -0.176 & 0.137 & -0.236 & -0.164 & -0.057 \\
\hline Construction & 0.009 & 0.004 & 0.005 & 0.046 & 0.040 & 0.001 \\
\hline Trade & 0.002 & -0.020 & 0.021 & -0.062 & -0.039 & -0.001 \\
\hline \multicolumn{7}{|l|}{ B. Expansion } \\
\hline All industries & 0.039 & 0.055 & -0.016 & -- & -- & -- \\
\hline Manufacturing & 0.017 & 0.083 & -0.066 & 0.112 & 0.098 & 0.022 \\
\hline Construction & 0.003 & 0.026 & -0.023 & 0.086 & -0.062 & 0.080 \\
\hline Trade & 0.029 & 0.057 & -0.027 & 0.066 & 0.018 & 0.018 \\
\hline
\end{tabular}

Note: The recession is Q3 2008-Q3 2009, the expansion Q2 2005-Q3 2008. V represents valueadded in the industry (for all industries, GDP), w represents labor costs, GDP represents the components of GDP. The sum of weighted residuals (column 6) reflects the change in employment due to unexpected change in lagged value added (see text). Manufacturing includes mining and trade includes hospitality sectors and transportation. 
Table 6: Correlates of employment and value added by sector

\begin{tabular}{|c|c|c|c|c|c|c|}
\hline & \multicolumn{2}{|c|}{ Manufacturing } & \multicolumn{2}{|c|}{ Construction } & \multicolumn{2}{|c|}{ Trade } \\
\hline & $\begin{array}{c}\text { Employ- } \\
\text { ment }_{t} \\
(2)\end{array}$ & $\begin{array}{c}\text { Value } \\
\text { added }_{t} \\
(3)\end{array}$ & $\begin{array}{c}\text { Employ- } \\
\text { ment }_{t} \\
(4)\end{array}$ & $\begin{array}{c}\text { Value } \\
\text { added }_{t} \\
\text { (5) }\end{array}$ & $\begin{array}{c}\text { Employ- } \\
\text { ment }_{t} \\
(6)\end{array}$ & $\begin{array}{c}\text { Value } \\
\text { added }_{t} \\
(7)\end{array}$ \\
\hline Value added $\mathrm{t}_{\mathrm{t}-1}$ & $\begin{array}{c}0.437 \\
(0.104)\end{array}$ & - & $\begin{array}{c}0.258 \\
(0.043)\end{array}$ & -- & $\begin{array}{c}0.301 \\
(0.113)\end{array}$ & - \\
\hline Value added $_{t-2}$ & $\begin{array}{c}0.148 \\
(0.060)\end{array}$ & -- & $\begin{array}{c}0.134 \\
(0.029)\end{array}$ & -- & $\begin{array}{c}0.099 \\
(0.057)\end{array}$ & -- \\
\hline Value added $d_{t-3}$ & $\begin{array}{c}0.098 \\
(0.061)\end{array}$ & -- & $\begin{array}{c}0.121 \\
(0.030)\end{array}$ & -- & $\begin{array}{c}0.026 \\
(0.070)\end{array}$ & -- \\
\hline Value added $\mathrm{t}_{\mathrm{t}-4}$ & $\begin{array}{c}0.280 \\
(0.092)\end{array}$ & -- & $\begin{array}{c}0.160 \\
(0.051)\end{array}$ & -- & $\begin{array}{l}-0.008 \\
(0.118)\end{array}$ & -- \\
\hline $\begin{array}{l}\text { Labor costs } \\
\text { per worker }\end{array}$ & $\begin{array}{l}-0.511 \\
(0.091)\end{array}$ & -- & $\begin{array}{l}-0.171 \\
(0.084)\end{array}$ & -- & $\begin{array}{l}-0.332 \\
(0.076)\end{array}$ & -- \\
\hline Consumption $_{\mathrm{t}}$ & -- & $\begin{array}{l}-0.120 \\
(0.510)\end{array}$ & -- & $\begin{array}{c}1.723 \\
(0.596)\end{array}$ & -- & $\begin{array}{c}1.323 \\
(0.208)\end{array}$ \\
\hline Investment $_{t}$ & -- & $\begin{array}{c}0.292 \\
(0.089)\end{array}$ & -- & $\begin{array}{c}0.688 \\
(0.109)\end{array}$ & -- & $\begin{array}{c}0.168 \\
(0.039)\end{array}$ \\
\hline $\begin{array}{l}\text { Government } \\
\text { spending }_{t}\end{array}$ & -- & $\begin{array}{c}0.442 \\
(0.221)\end{array}$ & -- & $\begin{array}{l}-0.011 \\
(0.235)\end{array}$ & -- & $\begin{array}{l}-0.180 \\
(0.061)\end{array}$ \\
\hline Exports $_{t}$ & -- & $\begin{array}{c}0.754 \\
(0.225)\end{array}$ & -- & $\begin{array}{l}-0.320 \\
(0.255)\end{array}$ & -- & $\begin{array}{c}0.282 \\
(0.073)\end{array}$ \\
\hline Imports $_{t}$ & -- & $\begin{array}{l}-0.358 \\
(0.170)\end{array}$ & -- & $\begin{array}{l}-0.399 \\
(0.198)\end{array}$ & -- & $\begin{array}{l}-0.303 \\
(0.075)\end{array}$ \\
\hline Trend & $\begin{array}{l}-0.013 \\
(0.001)\end{array}$ & $\begin{array}{l}-0.023 \\
(0.009)\end{array}$ & $\begin{array}{l}-0.006 \\
(0.001)\end{array}$ & $\begin{array}{l}-0.011 \\
(0.010)\end{array}$ & $\begin{array}{c}0.007 \\
(0.002)\end{array}$ & $\begin{array}{l}-0.009 \\
(0.004)\end{array}$ \\
\hline $\mathrm{R}^{2}$ & 0.98 & 0.77 & 0.93 & 0.87 & 0.97 & 0.99 \\
\hline Observations & 132 & 136 & 132 & 136 & 132 & 136 \\
\hline
\end{tabular}

Note: All variables are in logs except the trend. The independent variables except value added refer to the aggregate economy. Quarterly, seasonally adjusted data from 1970-2003. Labor costs include employer and employee social security payments and are adjusted for reimbursements related to short-time work. Trade includes hospitality sectors and transportation. Manufacturing includes mining. Newey-West standard errors based on four lags in parentheses. 
Table 7: Sources of changes in hours per worker 2008-2009

\begin{tabular}{|lccc|}
\hline & $\begin{array}{c}\text { Change } \\
\text { (hours) } \\
\end{array}$ & $\begin{array}{c}\text { Change } \\
\text { (percent of annual hours per worker) }\end{array}$ & $\begin{array}{c}\text { Share of hours } \\
\text { decline (percent) }\end{array}$ \\
\hline Short-time work & -13.4 & $(2)$ & 32 \\
Standard weekly hours & -10.1 & -1.0 & 24 \\
Overtime & -7.9 & -0.8 & 19 \\
Part-time share & -7.5 & -0.6 & 18 \\
Working time accounts & -7.0 & -0.6 & 17 \\
Calendar effect & -0.7 & -0.5 & 2 \\
Sick days & 0.1 & -0.1 & 0 \\
Second jobs & 0.6 & 0.0 & -1 \\
Vacation days & 4.6 & 0.0 & -11 \\
\hline Annual hours per worker & -41.3 & 0.3 & 100 \\
\hline
\end{tabular}

Source: IAB Working Time Calculation and authors' calculations.

Notes: Calculations based on change in yearly average from 2008 to 2009. The calendar effect reflects different numbers of working days in the two years. 
Table 8: The role of expectations in employment adjustment

\begin{tabular}{|lcc|}
\hline & $(1)$ & $(2)$ \\
\hline$\Delta$ GDP & 0.170 & 0.163 \\
& $(0.047)$ & $(0.038)$ \\
Labor costs per worker $\Delta \mathrm{w}$ & -0.038 & -0.049 \\
& $(0.035)$ & $(0.031)$ \\
Expectations balance $\mathrm{E}_{\mathrm{t}-2}$ & -- & 0.00013 \\
& & $(0.00003)$ \\
Constant & 0.0002 & 0.0014 \\
& $(0.0006)$ & $(0.0006)$ \\
\hline $\mathrm{R}^{2}$ & 0.18 & 0.38 \\
Observations & 135 & 134 \\
\hline
\end{tabular}

Note: The dependent variable is the change in log employment. All variables are in logs except the expectations balance. The balance of expectations is the difference between the share of firms expecting business conditions in six months to be better and the share expecting them to be worse. Quarterly, seasonally adjusted data from 1970-2003. Labor costs include employer and employee social security payments and are adjusted for reimbursements for related to short-time work. Newey-West standard errors based on four lags in parentheses. 
Table 9: Role of expectations in employment in the expansion 2005-2008

\begin{tabular}{|c|c|c|c|c|}
\hline \multirow[t]{2}{*}{ Change in employment } & \multicolumn{3}{|c|}{ Predicted change in employment } & Effect of \\
\hline & $\begin{array}{l}\text { No expectations } \\
\text { controls }\end{array}$ & $\begin{array}{l}\text { Expectations } \\
\text { controls }\end{array}$ & $\begin{array}{l}\text { Counterfactual } \\
\text { expectations }\end{array}$ & $\begin{array}{c}\text { changed } \\
\text { expectations } \\
(4)-(3)\end{array}$ \\
\hline$(1)$ & $(2)$ & (3) & (4) & $(5)$ \\
\hline 0.037 & 0.014 & 0.032 & 0.041 & 0.009 \\
\hline
\end{tabular}

Note: Values are reported for the period Q3 2005-Q3 2008. Predictions are based on one-quarter differenced regressions reported in Table 8. All regressions control for the change in GDP and labor costs. Variables except expectations are in logs. 
Table 10: Sources of changes in hours per worker 1996-2007

\begin{tabular}{|lccc|}
\hline & \multicolumn{2}{c|}{$\begin{array}{c}\text { Change per year } \\
\text { (hours) }\end{array}$} & $\begin{array}{c}\text { Double difference } \\
\text { (hours) }\end{array}$ \\
& $1996-2004$ & $2004-2007$ & $(2)-(1)$ \\
\hline Short-time work & $(1)$ & $(2)$ & 0.2 \\
Standard weekly hours & 0.3 & 0.5 & 5.3 \\
Overtime & -2.0 & 3.3 & 0.2 \\
Part-time share & -1.0 & -0.8 & 6.3 \\
Working time accounts & -13.4 & -7.1 & 1.3 \\
Calendar effect & -0.1 & 1.2 & -4.7 \\
Sick days & 1.1 & -3.6 & -1.8 \\
Second jobs & 2.8 & 1.0 & 0.2 \\
Vacation days & 1.0 & 1.2 & -1.5 \\
\hline Annual hours per worker & 2.1 & 0.6 & 5.7 \\
\hline
\end{tabular}

Source: IAB Working Time Calculation data and authors' calculations.

Notes: Annual data. The calendar effect reflects different numbers of working days across years. 
Figure 1: The Great Recession in the United States, Germany and United Kingdom, 2007-2010
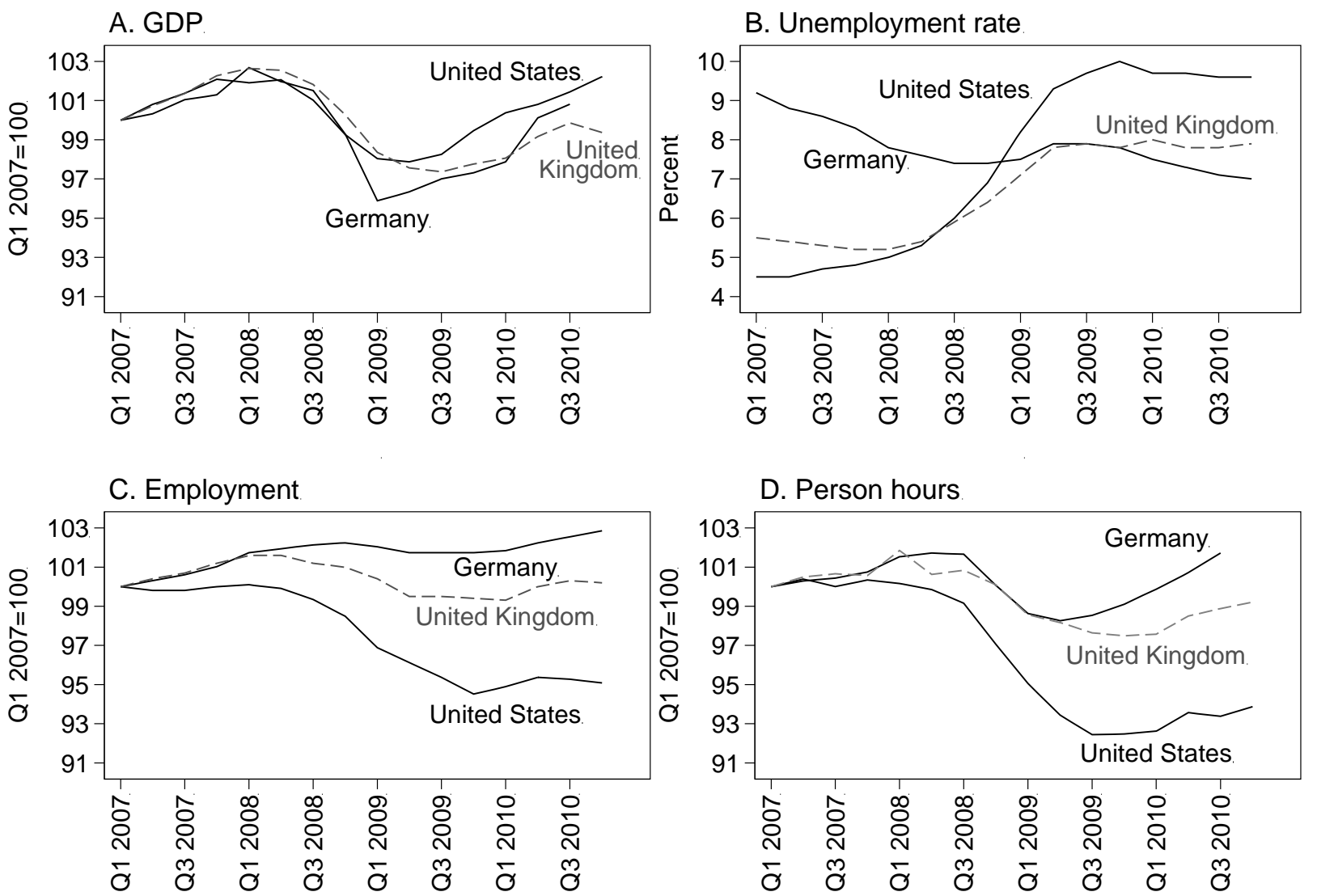

Note: Quarterly, seasonally adjusted data. Real GDP.

Source: GDP: Bureau of Economic Analysis, Federal Statistical Office, Office for National Statistics; unemployment and employment: comparable data from the Bureau of Labor Statistics; person-hours: Bart Holbijn estimates of total nonfarm hours, Federal Statistical Office, Office for National Statistics. 
Figure 2: Output and labor market outcomes in past German recessions
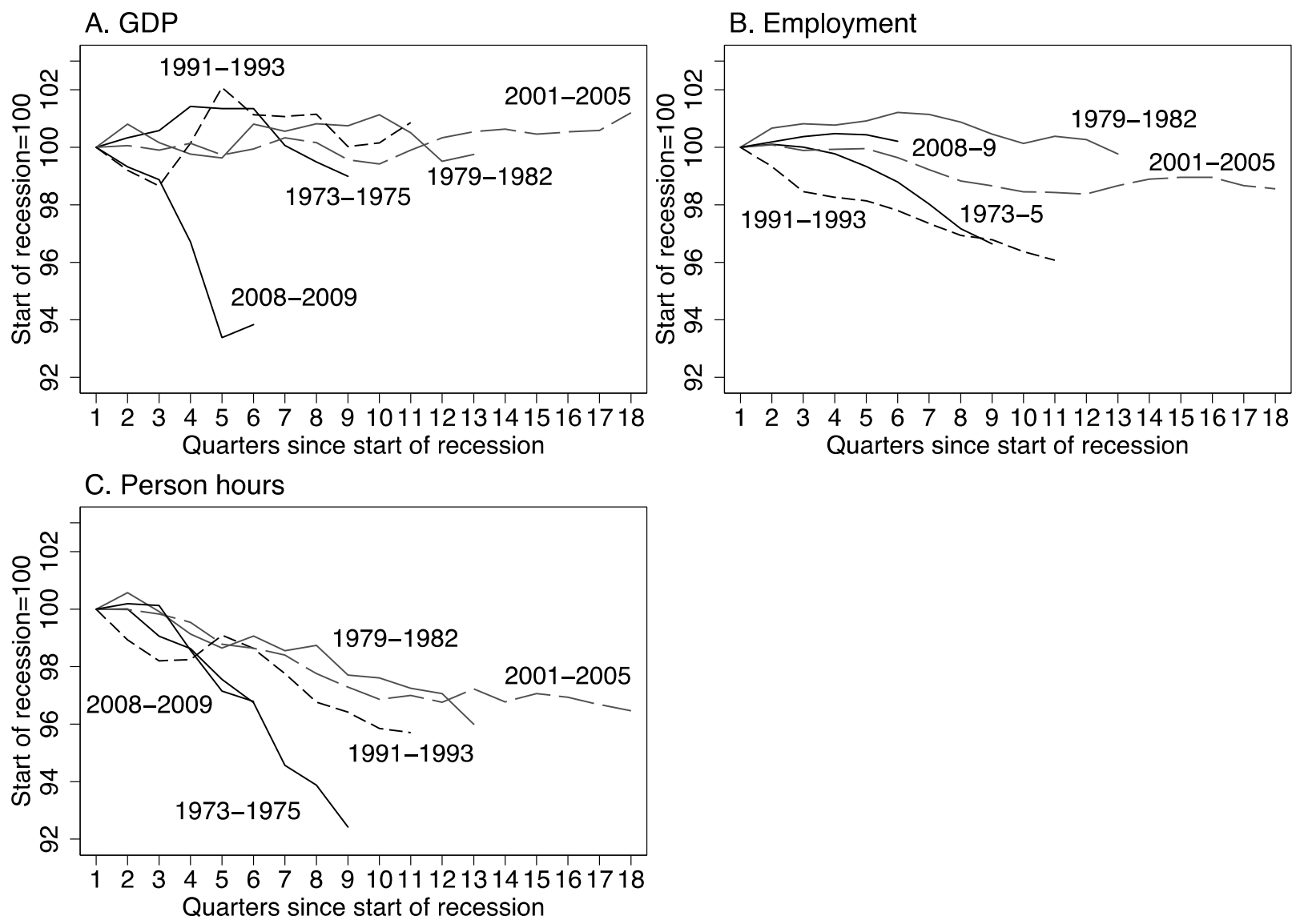

Note: Quarterly, seasonally adjusted data. Real GDP. Recession dates taken from the Sachverständigenrat (2010): Q2 1973-Q2 1975, Q4 1979-Q4 1982, Q1 1991-Q3 1993, Q1 $2001-$ Q2 2005, Q1 2008-Q2 2009.

Source: Federal Statistical Office. 
Figure 3: Components of GDP

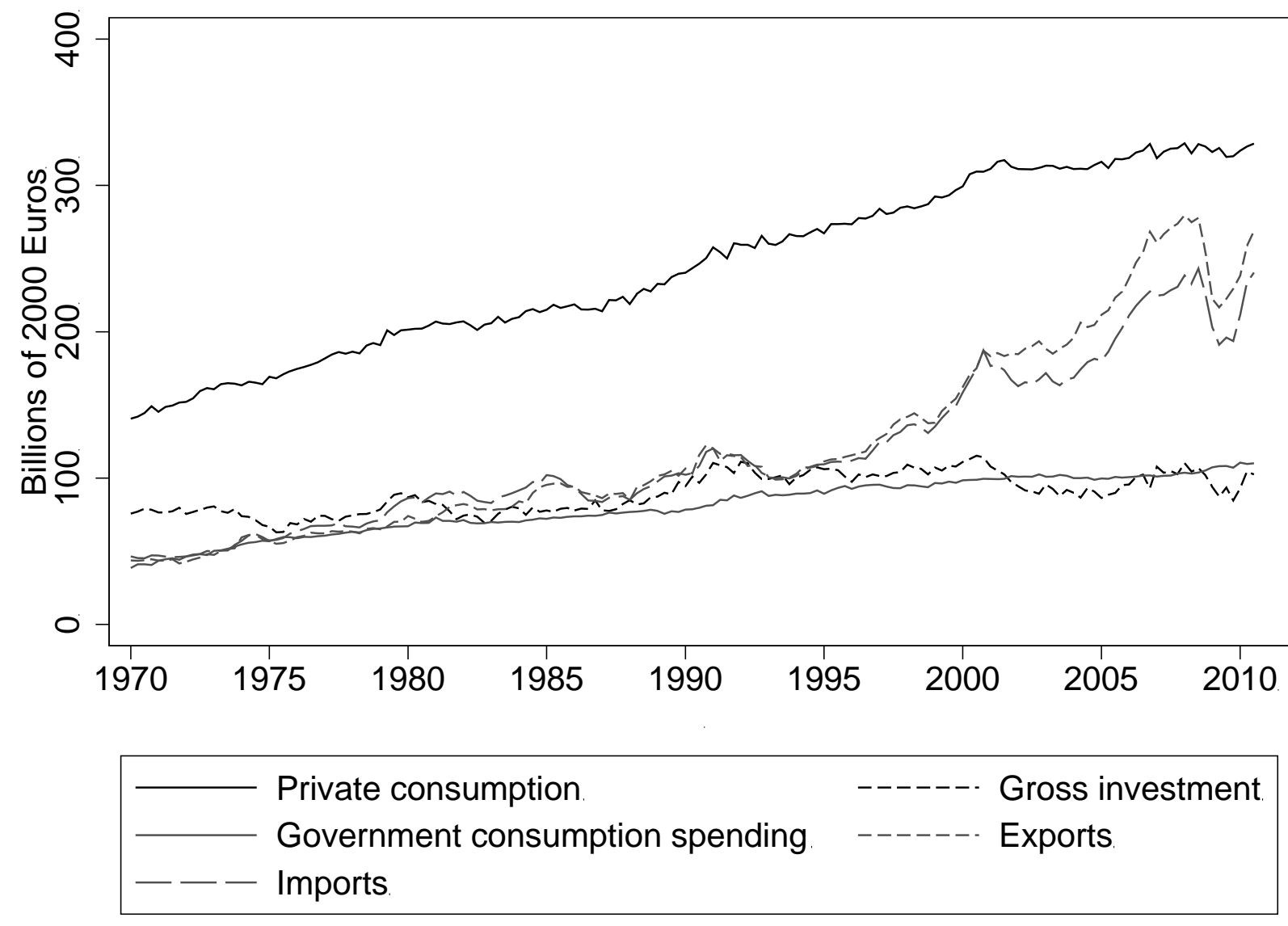

Note: Quarterly, seasonally adjusted data 1970-2010.

Source: Federal Statistical Office. 
Figure 4: Hours per worker and productivity in past German recessions
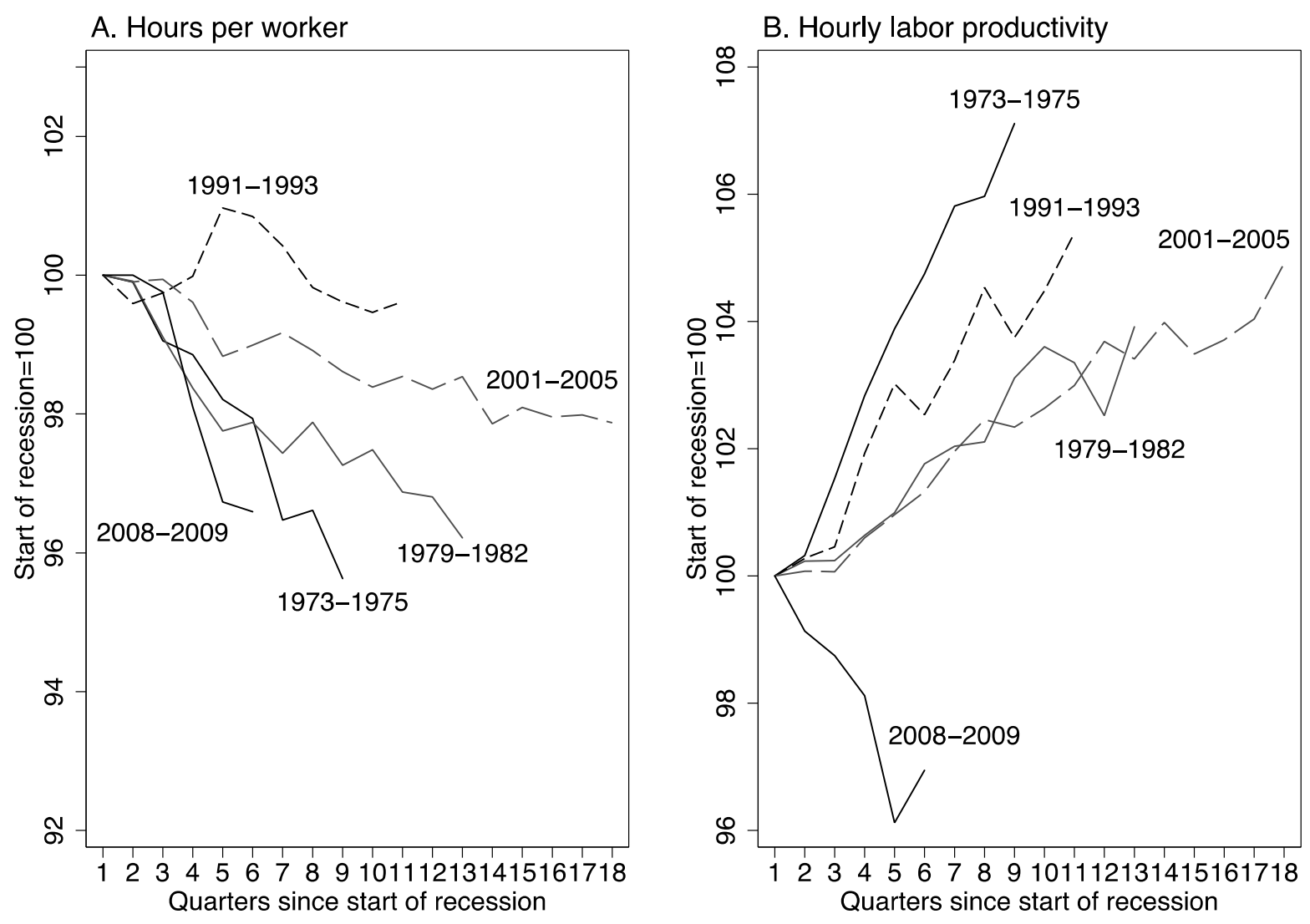

Note: Quarterly, seasonally adjusted data. Real labor productivity. Recession dates taken from the Sachverständigenrat (2010): Q2 1973-Q2 1975, Q4 1979-Q4 1982, Q1 1991-Q3 1993, Q1 2001Q2 2005, Q1 2008-Q2 2009.

Source: Federal Statistical Office. 
Figure 5: Actual and predicted log hours per worker

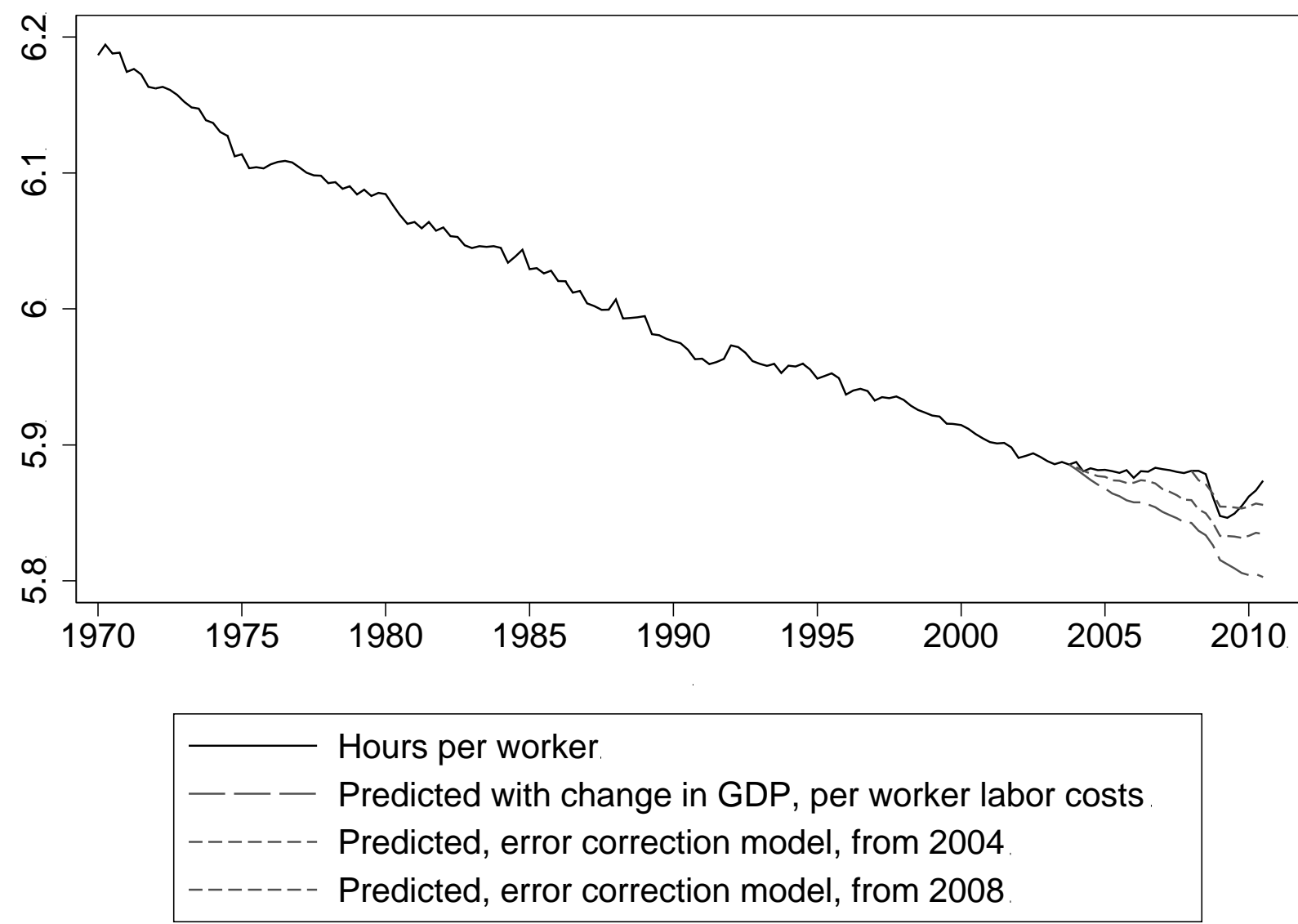

Note: Hours per worker are predicted using a one-quarter differenced regression or an error correction regression using quarterly, seasonally adjusted data from 1970-2003. Differences are cumulated either from Q1 2008 or Q1 2004. All variables are in logs. Hours per worker are per quarter.

Source: Federal Statistical Office and authors' calculations. 
Figure 6: Actual and predicted log employment

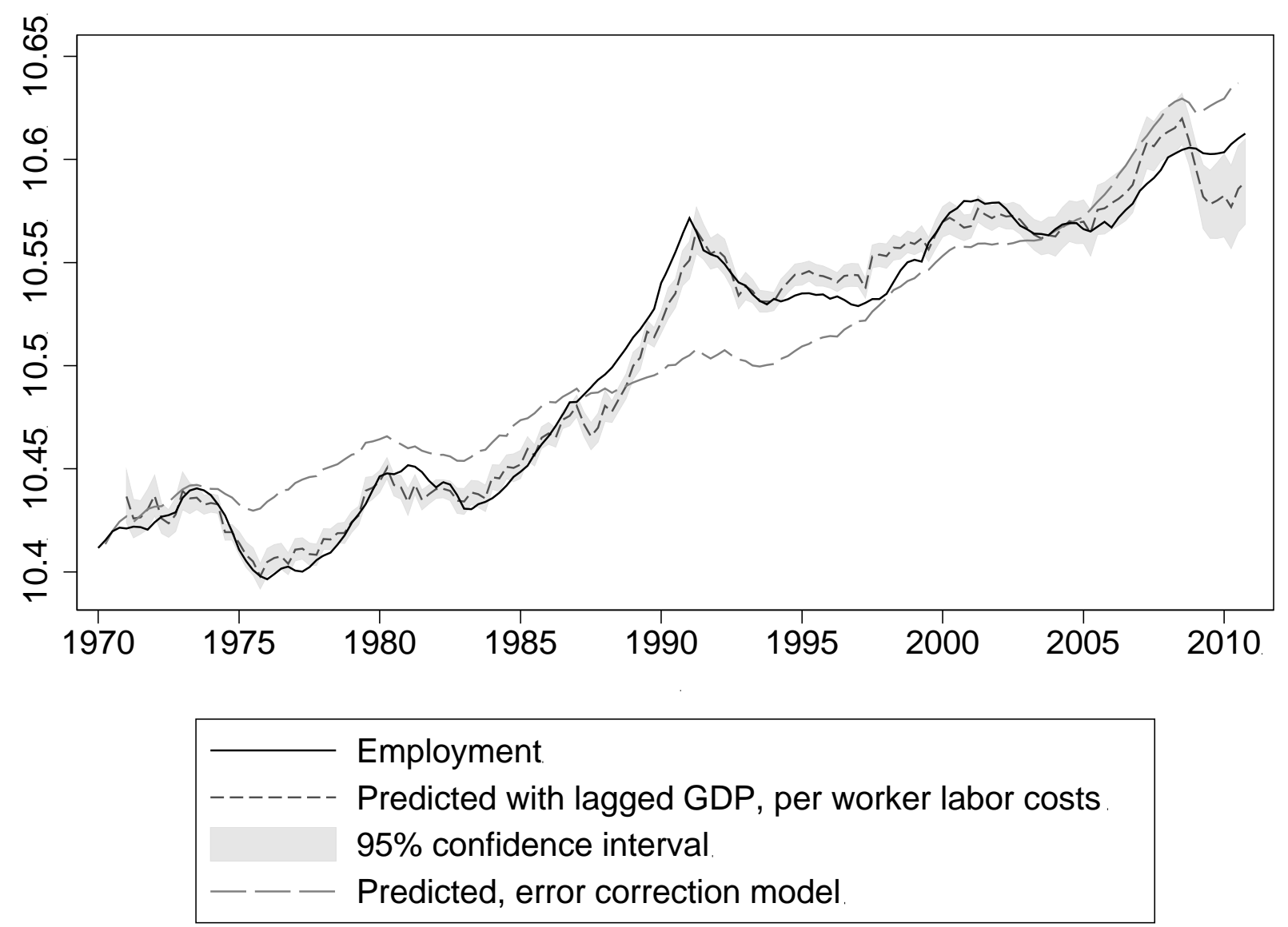

Note: Employment is predicted using a regression in levels or an error correction regression using quarterly, seasonally adjusted data from 1970-2003. All variables are in logs. Employment is in thousands.

Source: Federal Statistical Office and authors' calculations. 
Figure 7: Value added and employment by sector, 1970-2010
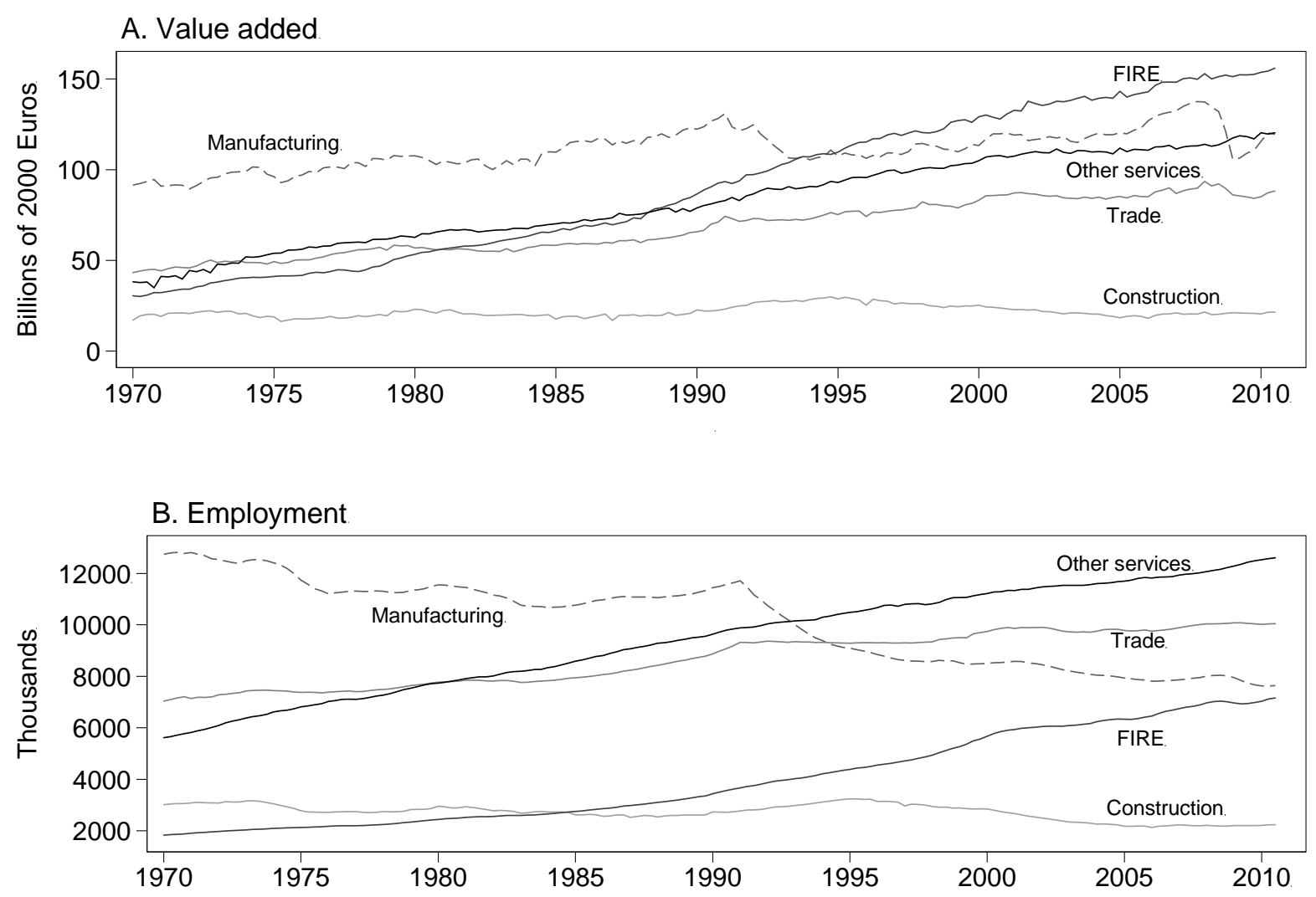

Note: Quarterly, seasonally adjusted data. Manufacturing includes mining; trade includes hospitality sectors and transportation; FIRE includes finance, insurance, real estate and other firm services. Other services include health, education and other public and personal services.

Source: Federal Statistical Office. 
Figure 8: Hours of work lost through short-time work 1970-2010

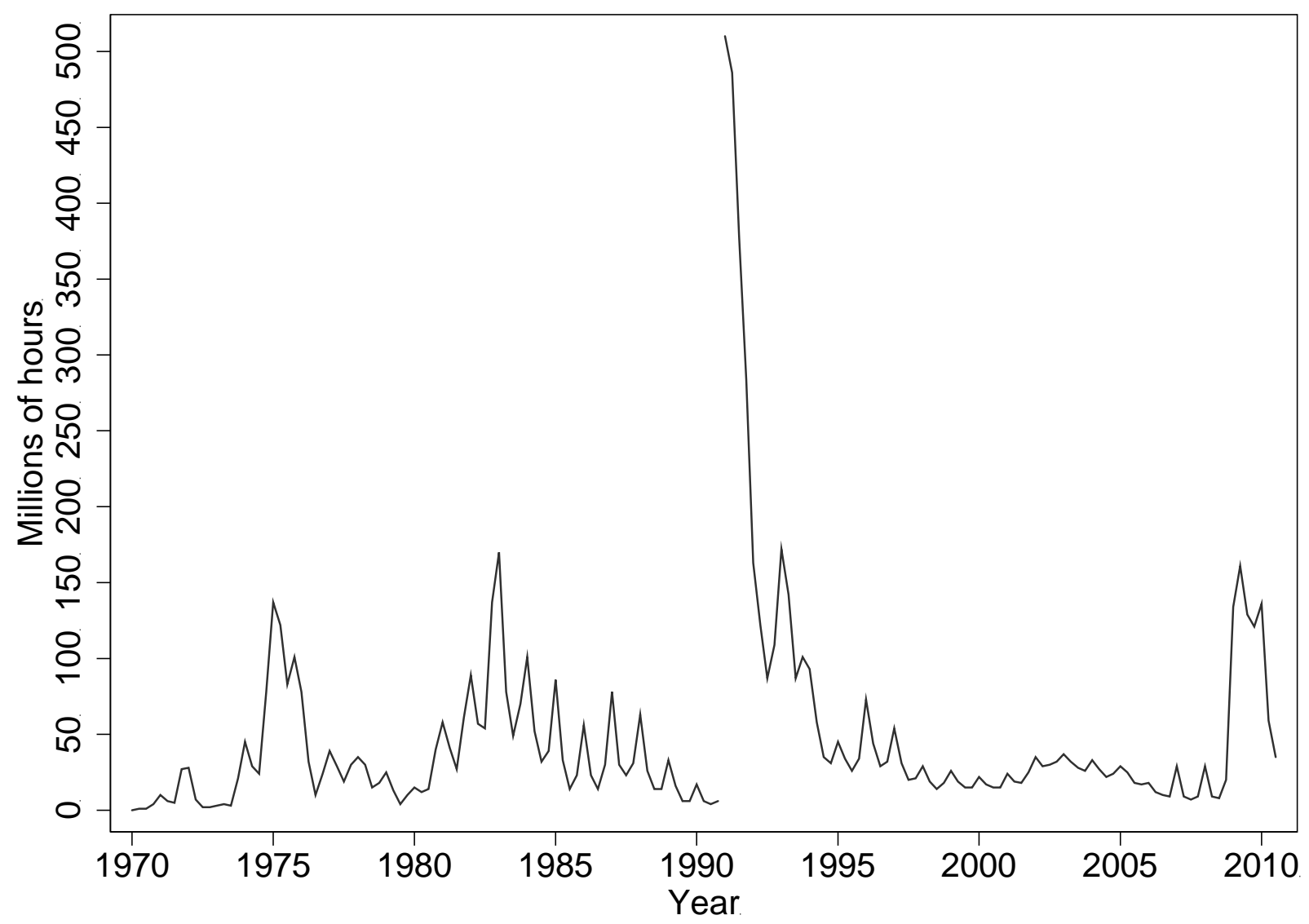

Note: Quarterly, seasonally unadjusted data, not adjusted to avoid break at unification.

Source: Institut für Arbeitsmarkt- und Berufsforschung. 
Figure 9: Labor costs and productivity per hour, labor's share



B. Costs and productivity, 2004-2010
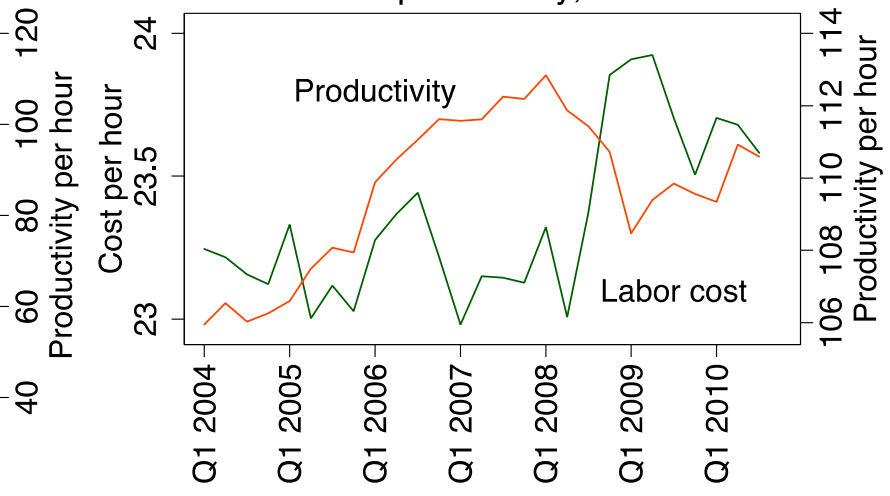

C. Unit labor costs/labor's share, 1970-2010

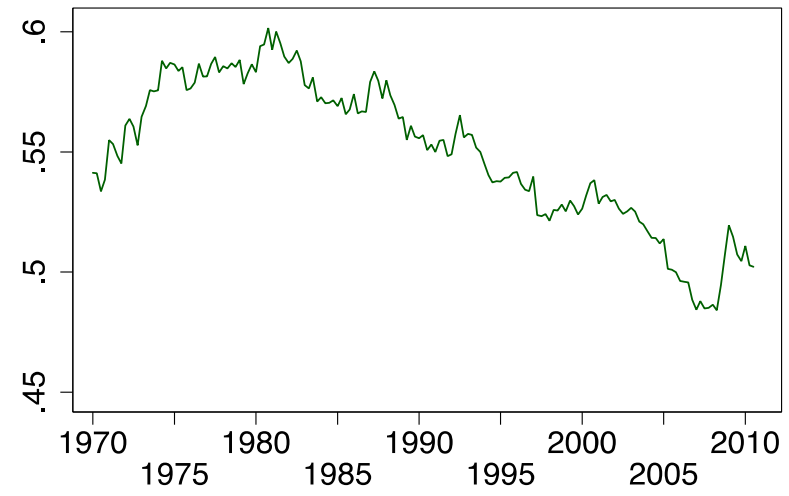

D. Unit labor costs/labor's share, 2004-2010

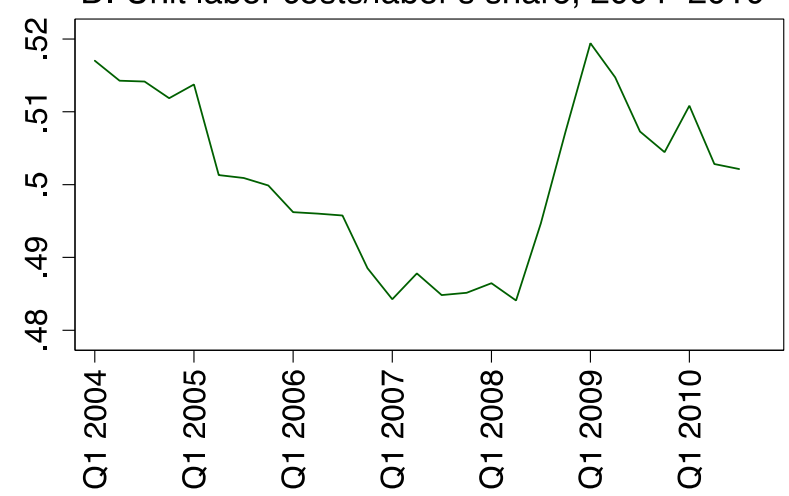

Note: Labor costs include employer and employee social security contributions, and adjusted for reimbursements related to short-time work. Labor productivity is output divided by hours worked, and is an index equal to 100 in 2000. All values are real. Unit labor costs are computed as labor costs divided by productivity. Quarterly, seasonally adjusted data.

Source: Federal Statistical Office. 


\section{Figure 10: IFO Business expectations and Current situation}
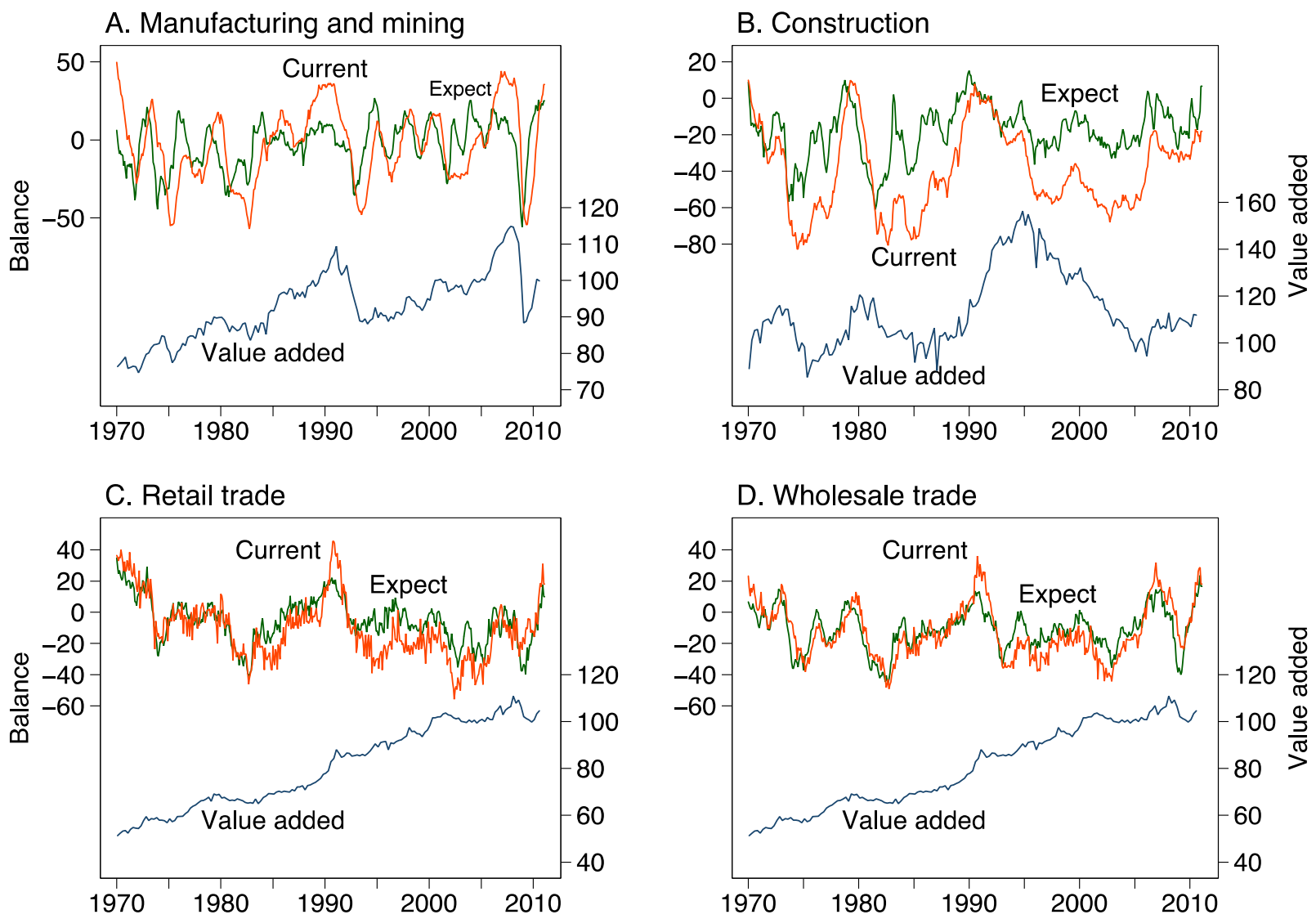

Note: Balance is the difference between the share of firms with positive and negative responses: for expectations the difference between better and worse; for current situation the difference between good and bad. Business expectations are for the coming six months. The firm responses for manufacturing exclude the food industry. Real, quarterly, seasonally adjusted value added is normalized so Q2 2005=100. The value added plotted in graphs C and D refers to both retail and wholesale trade, as well as hospitality and transportation. Expectations and current situation data are monthly, not seasonally adjusted.

Source: IFO Institute for Economic Research and Federal Statistical Office. 